Article

\title{
Chloroaluminate Ionic Liquid Immobilized on Magnetic Nanoparticles as a Heterogeneous Lewis Acidic Catalyst for the Friedel-Crafts Sulfonylation of Aromatic Compounds
}

\author{
Ngoc-Lan Thi Nguyen ${ }^{1}$, Quoc-Anh Nguyen ${ }^{1}$, Tien Khoa Le ${ }^{1}$, Thi Xuan Thi Luu ${ }^{1,2, *}$, Kim-Ngan Thi Tran ${ }^{1}$ \\ and Phuoc-Bao Pham ${ }^{1}$ \\ 1 Faculty of Chemistry, University of Science, 227 Nguyen Van Cu, Dist. 5, Ho Chi Minh 700000, Vietnam; \\ lanbmt07@gmail.com (N.-L.T.N.); nquocanh1996@gmail.com (Q.-A.N.); ltkhoa@hcmus.edu.vn (T.K.L.); \\ thikimngan.tran@gmail.com (K.-N.T.T.); pphuocbao@gmail.com (P.-B.P.) \\ 2 Faculty of Chemistry, Vietnam National University of Hochiminh City, Ho Chi Minh 700000, Vietnam \\ * Correspondence: 1txthi@hcmus.edu.vn
}

check for updates

Citation: Nguyen, N.-L.T.; Nguyen, Q.-A.; Le, T.K.; Luu, T.X.T.; Tran,

K.-N.T.; Pham, P.-B. Chloroaluminate

Ionic Liquid Immobilized on

Magnetic Nanoparticles as a

Heterogeneous Lewis Acidic Catalyst for the Friedel-Crafts Sulfonylation of Aromatic Compounds. Molecules 2022, 27, 1644. https://doi.org/ $10.3390 /$ molecules 27051644

Academic Editors: Luísa Margarida Martins, Isidro M. Pastor and Maria Luisa Di Gioia

Received: 27 January 2022

Accepted: 21 February 2022

Published: 2 March 2022

Publisher's Note: MDPI stays neutral with regard to jurisdictional claims in published maps and institutional affiliations.

Copyright: (C) 2022 by the authors. Licensee MDPI, Basel, Switzerland. This article is an open access article distributed under the terms and conditions of the Creative Commons Attribution (CC BY) license (https:// creativecommons.org/licenses/by/ $4.0 /)$.

\begin{abstract}
Chloroaluminate ionic liquid bound on magnetic nanoparticles $\left(\mathrm{Fe}_{3} \mathrm{O}_{4} @ \mathrm{O}_{2} \mathrm{Si}[\mathrm{PrMIM}] \mathrm{Cl} \cdot \mathrm{AlCl}_{3}\right)$ was prepared and used as a heterogenous Lewis acidic catalyst for the Friedel-Crafts sulfonylation of aromatic compounds with sulfonyl chlorides or $p$-toluenesulfonic anhydride. The catalyst's stability, efficiency, easy recovery, and high recyclability without considerable loss of catalytic capability after four recycles were evidence of its advantages. Furthermore, the stoichiometry, wide substrate scope, short reaction time, high yield of sulfones, and solvent-free reaction condition also made this procedure practical, ecofriendly, and economical.
\end{abstract}

Keywords: sulfonylation; magnetic nanoparticles; sulfones; ionic liquids; sulfonic anhydride

\section{Introduction}

Sulfones, one of the most common organosulfur compounds, have tremendous applications in chemical processes [1,2], medicinal chemistry, and drug syntheses owing to their various biological activities; for instance, anti-inflammatory [3,4], anti-HIV [5], antimalarial $[6,7]$, anticancer [8], and antimicrobial $[9,10]$, and as a cysteine protease inhibitor [11].

Widespread synthetic routes of sulfones via the oxidation of the corresponding sulfides or sulfoxides [12-14], the sulfonylation of chloropyridine derivatives by sulfinate salts [15], the arylation of sulfinate salts by diaryliodonium salts [16], the formation of a C-S bond via the reaction of various silyl triflate and arenesulfinate salts [17], the addition to alkynes by sulfinate salts [18], the oxidative cyclization of phenyl propiolates with sulfinic acids initiated by visible light [19], the decarboxylative C-S cross-coupling of cinnamic acid with benzenesulfinate salts promoted by iodine [20], and the Friedel-Crafts sulfonylation have been developed. Among numerous approaches to sulfone preparations, aryl sulfones have been synthesized, preferably via the Friedel-Crafts sulfonylation reactions between activated arenes and sulfonylating reagents in the presence of catalysts; e.g., Lewis acidic salts [21-26], $\mathrm{Zn}$ [27], In/dioxane [28], $\mathrm{MoO}_{2} \mathrm{Cl}_{2}$ [29], metal triflate [30,31], $\mathrm{Fe}(\mathrm{OH})_{3}$ [32], nafion- $\mathrm{H}$ [33], $\mathrm{Fe}(\mathrm{III})$-exchanged montmorillonite [34], $\mathrm{Ps}-\mathrm{AlCl}_{3}$ and $\mathrm{SiO}_{2}-\mathrm{AlCl}_{3}[35,36]$, Lewis acidic salt-based ionic liquids [37,38], and $\mathrm{P}_{2} \mathrm{O}_{5}$ supported on $\mathrm{Al}_{2} \mathrm{O}_{3}$ [39] or $\mathrm{SiO}_{2}$ [40].

Within the tendency of scientific and technological improvement, environmental assessment has been mainly paid attention. In recent decades, ionic liquids (ILs), as well as functionalized ionic liquids, play important roles as solvents and homogeneous catalysts in several organic synthesis processes, owing to their low vapor pressure, thermal stability, high ability to dissolve many inorganic and organic compounds [41]. Homogeneous catalysts are always dissolved easily in various organic solvents or reaction media, therefore it is difficult to recover and recycle catalysts used. Contrarily, heterogeneous catalysts could be 
recovered and recycled conveniently and efficiently, although their dispersion in reaction media have not been carried out well. To overcome these problems in the dispersion, recovery, and recycling of catalysts, ionic liquids have been immobilized onto solid materials such as organic polymers [42-44], inorganic supports (e.g., silica, alumina) [45-48], and magnetic nanoparticles (MNPs) [49-55]. The improved catalysts have possessed the combined properties of homogeneous and heterogeneous catalysts, consisting of a larger surface area and catalyst-loading capacity, better dispersity in reaction media, and simple separation. In general, MNPs are selected as excellent solid supports for ILs, owing to a convenient removal of the catalyst by using an external magnet without filtration or centrifugation [56].

Using the advantages of magnetic nanoparticles in catalysis, in this work, we developed a magnetic nanoparticle- $-\mathrm{Fe}_{3} \mathrm{O}_{4}$ linked acidic ionic liquid as a green and efficient catalyst to be used for the Friedel-Crafts sulfonylation of activated arenes or polyarenes with sulfonyl chloride or sulfonic ahydride (Scheme 1). Magnetic nanoparticle- $\mathrm{Fe}_{3} \mathrm{O}_{4}$ linked acidic ionic liquids have been used for several transformations, such as three-component reactions of benzaldehyde derivatives, urea/thiourea, and acetoacetate [50]; benzaldehyde derivatives, $\beta$-naphthol, and 1,3-cyclohexandione derivatives [57]; and benzaldehyde derivatives, aniline derivatives, and 2-mercaptoethanoic acid [58].

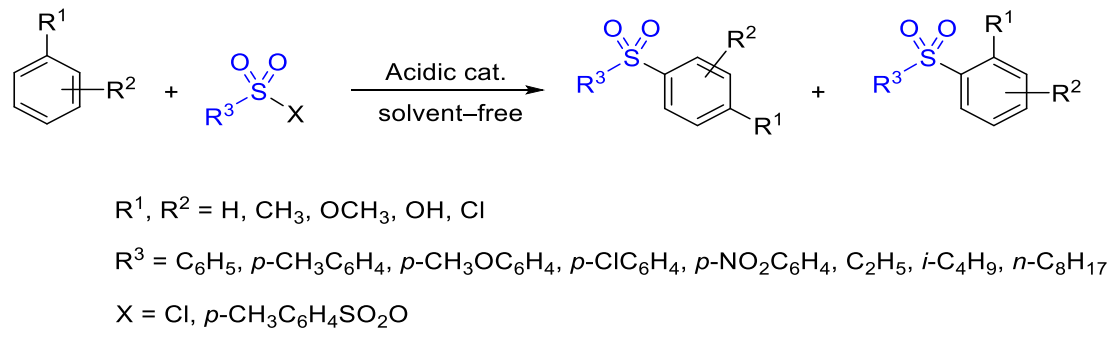

Scheme 1. The Friedel-Crafts sulfonylation catalyzed by $\mathrm{Fe}_{3} \mathrm{O}_{4} @ \mathrm{O}_{2} \mathrm{Si}[\mathrm{PrMIM}] \mathrm{Cl} \cdot \mathrm{AlCl}_{3}$.

\section{Results and Discussion}

At the beginning of this work, based on the disadvantages of the recovery and recycling of the chloroaluminate ionic liquid used for the Friedel-Crafts sulfonylation between toluene and benzenesulfonyl chloride [59], several magnetic nanoparticles bound by a Lewis/Brønsted acidic ionic liquid, such as $\mathrm{Fe}_{3} \mathrm{O}_{4} @ \mathrm{O}_{2} \mathrm{Si}[\mathrm{PrMIM}] \mathrm{HSO}_{4}, \mathrm{MgFe}_{2} \mathrm{O}_{4} @ \mathrm{O}_{2} \mathrm{Si}[\mathrm{Pr}$ $\mathrm{MIM}] \mathrm{Cl} \cdot \mathrm{AlCl}_{3}$, and $\mathrm{Fe}_{3} \mathrm{O}_{4} @ \mathrm{O}_{2} \mathrm{Si}[\mathrm{PrMIM}] \mathrm{Cl} \cdot \mathrm{AlCl}_{3}$, were developed and evaluated under a solvent-free sulfonylation reaction (entries 1-3, Table 1). Consequently, $\mathrm{Fe}_{3} \mathrm{O}_{4} @ \mathrm{O}_{2} \mathrm{Si}[\mathrm{PrMIM}]$ $\mathrm{Cl} \cdot \mathrm{AlCl}_{3}$ was selected as the best acidic catalyst among the heterogeneous catalysts used, owing to its efficiency (Table 1 ).

Table 1. Nature of the acidic catalysts' influences on the Friedel-Crafts sulfonylation of toluene with benzenesulfonyl chloride ${ }^{a}$.

\begin{tabular}{|c|c|c|c|}
\hline $\mathrm{CH}_{3}$ & $\underset{\text { Acidic cat. }}{\longrightarrow}$ & O "s, $\mathrm{CH}^{\mathrm{CH}_{3}}$ & $3 a^{\prime \prime}$ \\
\hline Entry & Acidic Catalyst & Ratio of $3 a: 3 a^{\prime}: 3 a^{\prime \prime}$ & Yield $(\%){ }^{b}$ \\
\hline 1 & $\mathrm{Fe}_{3} \mathrm{O}_{4} @ \mathrm{O}_{2} \mathrm{Si}[\mathrm{PrMIM}] \mathrm{HSO}_{4}(0.2 \mathrm{~g})$ & $56: 41: 3$ & 63 \\
\hline 2 & $\mathrm{MgFe}_{2} \mathrm{O}_{4} @ \mathrm{O}_{2} \mathrm{Si}[\mathrm{PrMIM}] \mathrm{Cl} \cdot \mathrm{AlCl}_{3}(0.2 \mathrm{~g})$ & 63:31:6 & 57 \\
\hline 3 & $\mathrm{Fe}_{3} \mathrm{O}_{4} @ \mathrm{O}_{2} \mathrm{Si}[\mathrm{PrMIM}] \mathrm{Cl} \cdot \mathrm{AlCl}_{3}(0.1 \mathrm{~g})$ & $49: 44: 7$ & 78 \\
\hline 4 & $\mathrm{Fe}_{3} \mathrm{O}_{4} @ \mathrm{O}_{2} \mathrm{Si}[\mathrm{PrMIM}] \mathrm{Cl} \cdot \mathrm{AlCl}_{3}(0.2 \mathrm{~g})$ & 55:39:6 & 85 \\
\hline 5 & $\mathrm{Fe}_{3} \mathrm{O}_{4} @ \mathrm{O}_{2} \mathrm{Si}[\mathrm{PrMIM}] \mathrm{Cl} \cdot \mathrm{AlCl}_{3}(0.3 \mathrm{~g})$ & $47: 46: 7$ & 86 \\
\hline
\end{tabular}

a The reaction of toluene $(1.0 \mathrm{mmol})$ and benzenesulfonyl chloride $(1.0 \mathrm{mmol})$ was performed under conventional heating for $4 \mathrm{~h}$ at $110{ }^{\circ} \mathrm{C} .{ }^{\mathrm{b}}$ Yields were calculated based on the GC/FID analyses. 


\subsection{Catalyst Characterization}

Magnetic fine particles were continuously prepared by coprecipitation of iron(II) and iron(III) salts at $80^{\circ} \mathrm{C}$. The precipitated fine particles were characterized by XRD for the structural determination (Figure 1), and by FT-IR spectra (Figure 2a) and SEM for the crystallite size (Figure 3a). The XRD pattern of $\mathrm{Fe}_{3} \mathrm{O}_{4}$ showed that five diffraction peaks appeared at around $30.20^{\circ}, 35.56^{\circ}, 43.14^{\circ}, 57.06^{\circ}$, and $62.59^{\circ}$, which corresponded to the crystallographic planes ((220), (311), (400), (511), and (440) lines, respectively) of the magnetite $\mathrm{Fe}_{3} \mathrm{O}_{4}$ phase [60]. In addition, the SEM micrograph of the $\mathrm{Fe}_{3} \mathrm{O}_{4}$ also displayed that cubic-shaped particles in agglomerated states reached a nanoparticle diameter of approximately $20.0 \mathrm{~nm}$ (Figure 3a). Subsequently, the heterogeneous catalyst, $\mathrm{Fe}_{3} \mathrm{O}_{4} @ \mathrm{O}_{2} \mathrm{Si}[\mathrm{PrMIM}] \mathrm{Cl} \cdot \mathrm{AlCl}_{3}$, was prepared from magnetic nanoparticles, 3-methyl-1-(3-trimethoxysilylpropyl)-1H-imidazol3-ium chloride, and aluminum chloride as described in Scheme 2, and then characterized by XRD (Figure 1), FT-IR (Figure 2c), SEM and TEM (Figure 3b,c), EDX (Figure 4), TGA (Figure 5), VSM (Figure 6), BET, and ICP-MS.

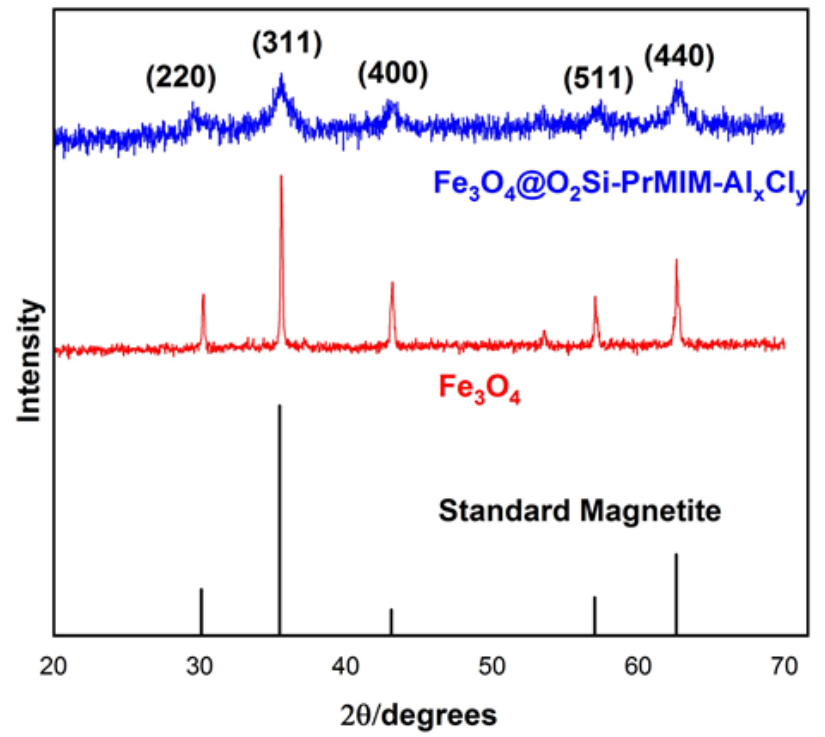

Figure 1. XRD patterns of $\mathrm{Fe}_{3} \mathrm{O}_{4}, \mathrm{Fe}_{3} \mathrm{O}_{4} @ \mathrm{O}_{2} \mathrm{Si}[\mathrm{PrMIM}] \mathrm{Cl} \cdot \mathrm{AlCl}_{3}$, and standard magnetite.

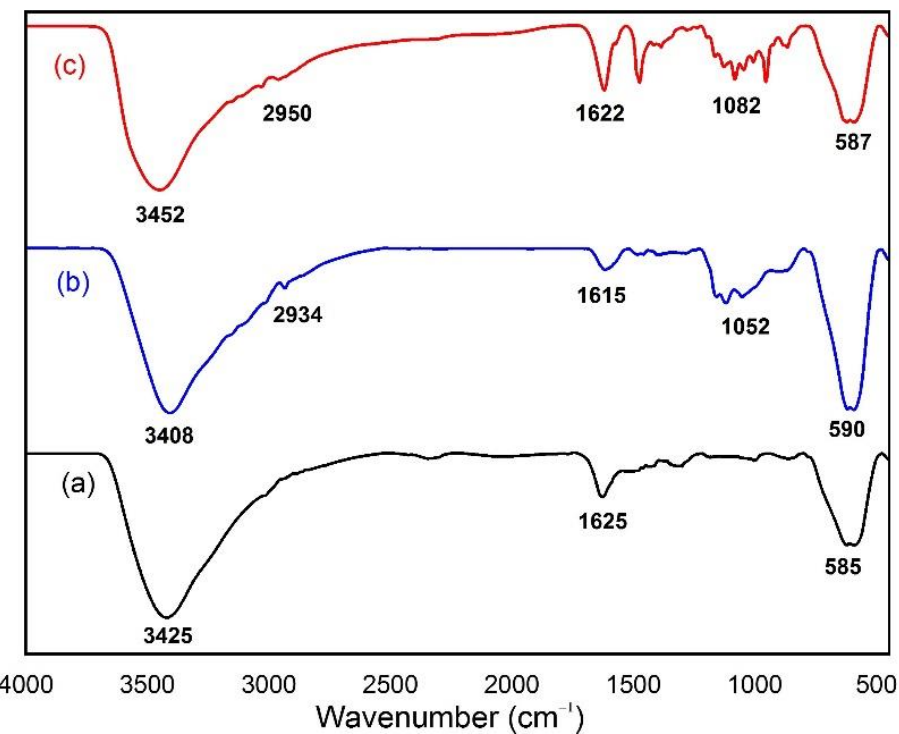

Figure 2. FT-IR spectra of $\mathrm{Fe}_{3} \mathrm{O}_{4}(\mathbf{a}), \mathrm{Fe}_{3} \mathrm{O}_{4} @ \mathrm{O}_{2} \mathrm{Si}[\mathrm{PrMIM}] \mathrm{Cl}(\mathbf{b})$, and $\mathrm{Fe}_{3} \mathrm{O}_{4} @ \mathrm{O}_{2} \mathrm{Si}[\mathrm{PrMIM}] \mathrm{Cl} \cdot \mathrm{AlCl}_{3}$ (c). 

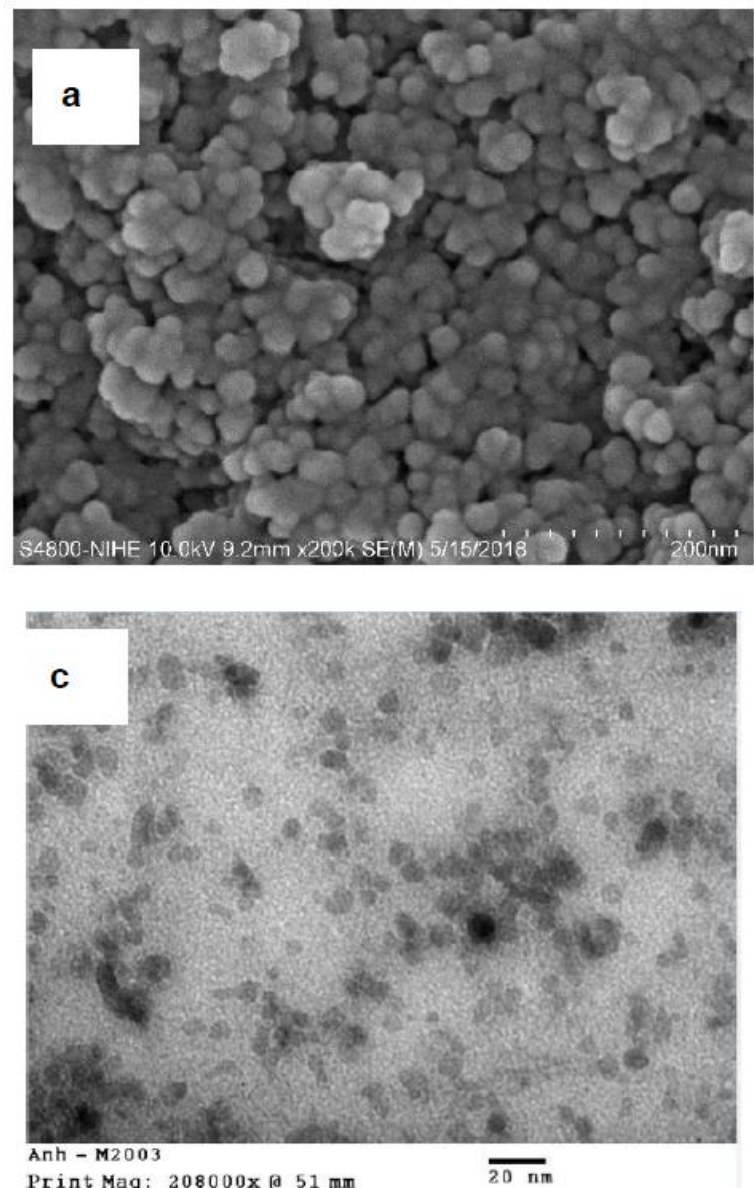

Figure 3. Nanoparticles of $\mathrm{Fe}_{3} \mathrm{O}_{4}$ : $\mathrm{SEM}$ (a) and catalyst $\mathrm{Fe}_{3} \mathrm{O}_{4} @ \mathrm{O}_{2} \mathrm{Si}[\mathrm{PrMIM}] \mathrm{Cl} \cdot \mathrm{AlCl}_{3}: \mathrm{SEM}$ (b) TEM (c); and particle size distribution (d).

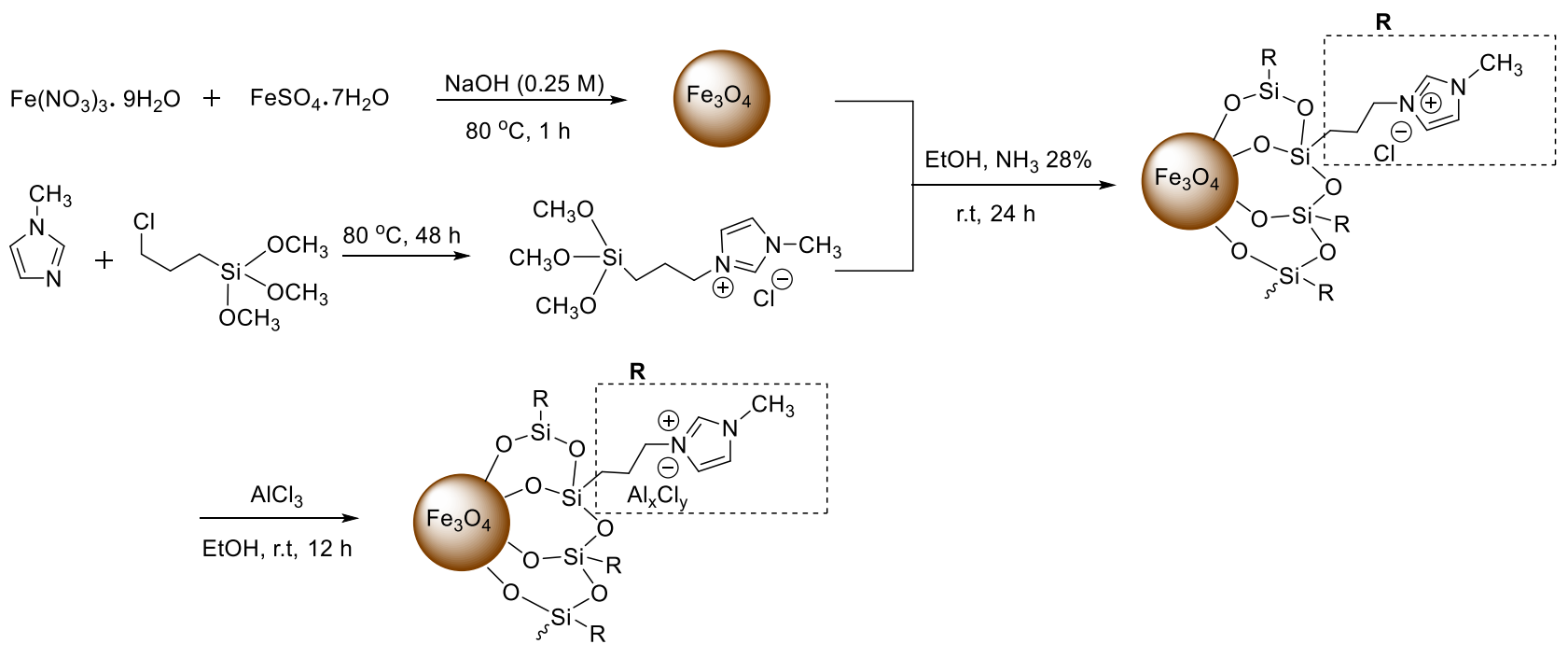

Scheme 2. The preparation of $\mathrm{Fe}_{3} \mathrm{O}_{4} @ \mathrm{O}_{2} \mathrm{Si}[\mathrm{PrMIM}] \mathrm{Cl} \cdot \mathrm{AlCl}_{3}$. 


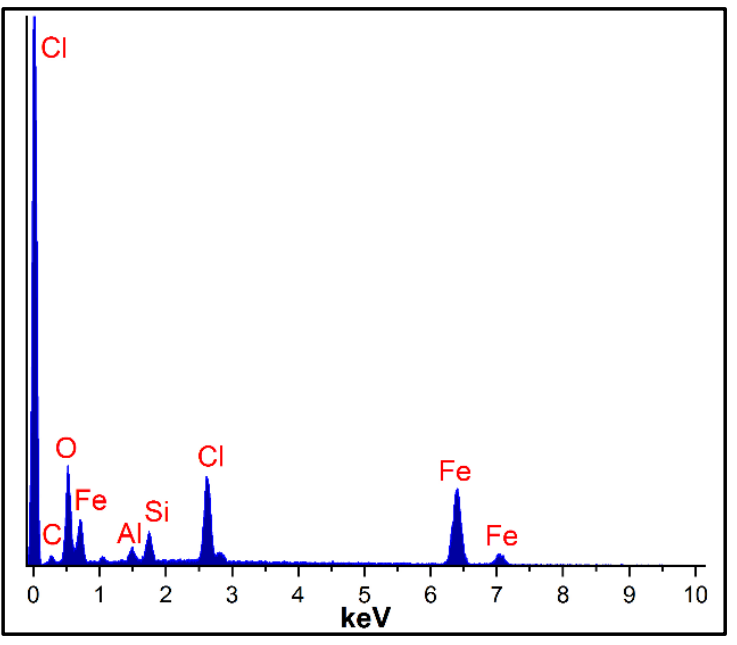

Figure 4. EDX spectrum of $\mathrm{Fe}_{3} \mathrm{O}_{4} @ \mathrm{O}_{2} \mathrm{Si}[\mathrm{PrMIM}] \mathrm{Cl} \cdot \mathrm{AlCl}_{3}$.

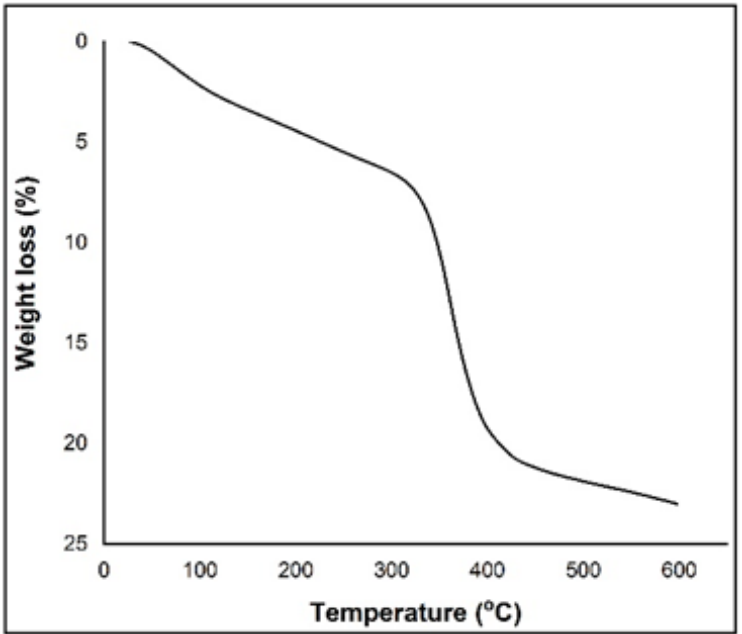

Figure 5. TGA diagram for $\mathrm{Fe}_{3} \mathrm{O}_{4} @ \mathrm{O}_{2} \mathrm{Si}[\mathrm{PrMIM}] \mathrm{Cl} \cdot \mathrm{AlCl}_{3}$.

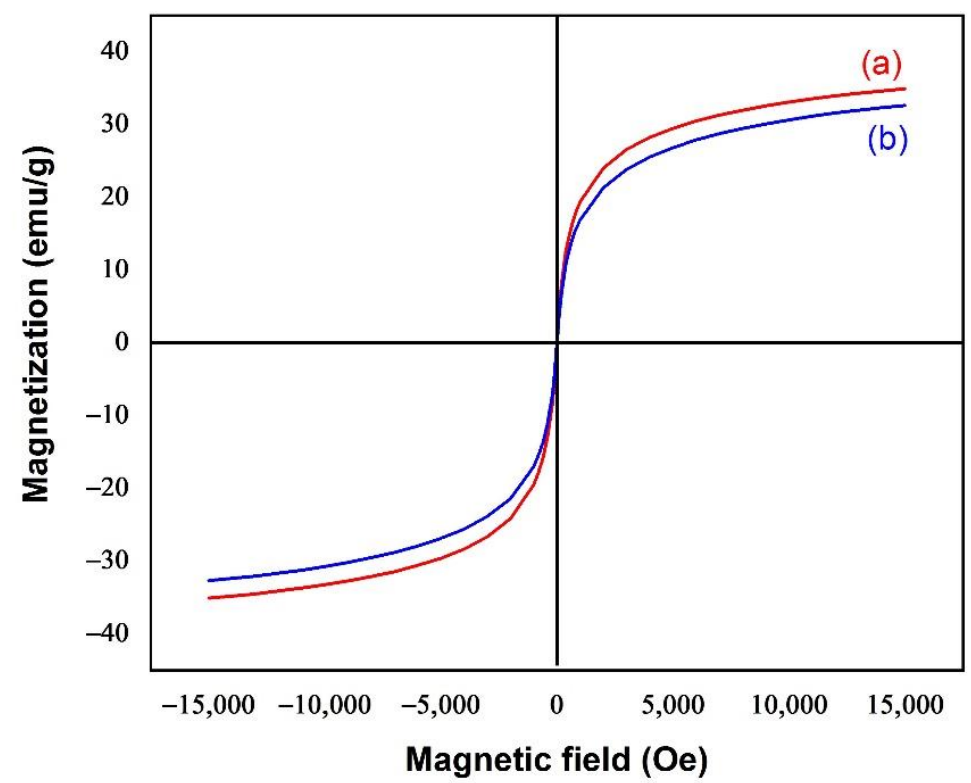

Figure 6. VSM curve for $\mathrm{Fe}_{3} \mathrm{O}_{4}(\mathbf{a})$ and $\mathrm{Fe}_{3} \mathrm{O}_{4} @ \mathrm{O}_{2} \mathrm{Si}[\mathrm{PrMIM}] \mathrm{Cl} \cdot \mathrm{AlCl}_{3}$ (b). 
In the XRD pattern of the $\mathrm{Fe}_{3} \mathrm{O}_{4} @ \mathrm{O}_{2} \mathrm{Si}[\mathrm{PrMIM}] \mathrm{Cl} \cdot \mathrm{AlCl}_{3}$ sample, these characteristic peaks were still present, but their intensities were dramatically decreased. The presence of ionic liquid in this sample was able to affect to the crystallinity of the magnetite phase (Figure 1).

The influence of the ionic liquid on the surface of the $\mathrm{Fe}_{3} \mathrm{O}_{4}$ was also investigated via FT-IR spectra (Figure 2). In the FT-IR spectrum of $\mathrm{Fe}_{3} \mathrm{O}_{4}$, three peaks were clearly detected at 3425,1625 , and $585 \mathrm{~cm}^{-1}$, which were respectively attributed to $\mathrm{O}-\mathrm{H}$ stretching, $\mathrm{O}-\mathrm{H}$ bending, and $\mathrm{Fe}-\mathrm{O}$ stretching vibrations. When the $\mathrm{Fe}_{3} \mathrm{O}_{4}$ particles were combined with the ionic liquid, new peaks were observed at 2950 and $1082 \mathrm{~cm}^{-1}$, in which the signal at $2950 \mathrm{~cm}^{-1}$ was obviously assigned to the aliphatic $\mathrm{C}-\mathrm{H}$ stretching vibration of the propyl group, and the latter signal at $1082 \mathrm{~cm}^{-1}$ belonged to the $\mathrm{Si}-\mathrm{O}$ stretching vibration. This proved that the immobilization of the ionic liquid on the $\mathrm{Fe}_{3} \mathrm{O}_{4}$ surface occurred successfully.

The surface morphology of the $\mathrm{Fe}_{3} \mathrm{O}_{4} @ \mathrm{O}_{2} \mathrm{Si}[\mathrm{PrMIM}] \mathrm{Cl} \cdot \mathrm{AlCl}_{3}$ was also compared with that of the $\mathrm{Fe}_{3} \mathrm{O}_{4}$ by scanning electron microscopy (SEM). As shown in Figure 3a, the $\mathrm{Fe}_{3} \mathrm{O}_{4}$ sample consisted of agglomerated particles with sizes varying from 20 to $40 \mathrm{~nm}$. Interestingly, the SEM and TEM images of $\mathrm{Fe}_{3} \mathrm{O}_{4} @ \mathrm{O}_{2} \mathrm{Si}[\mathrm{PrMIM}] \mathrm{Cl} \cdot \mathrm{AlCl}_{3}$ (Figure 3b,c) showed the presence of a liquid layer covering the surface of the magnetic particles. The size distribution of the magnetic nanoparticles modified by chloroaluminate ionic liquid varied in the range of $6 \mathrm{~nm}$ to $14 \mathrm{~nm}$ (Figure 3d). The aggregation of nanoparticles prevented by the presence of chloroaluminate ionic liquid immobilized on magnetic nanoparticles was the reason for the size reduction of the $\mathrm{Fe}_{3} \mathrm{O}_{4}$ particles.

The elemental composition determined by energy dispersive X-ray spectroscopy (EDX) illustrated that the catalyst contained carbon $(\mathrm{C})$, chlorine $(\mathrm{Cl})$, aluminum $(\mathrm{Al})$, oxygen $(\mathrm{O})$, and silicon $(\mathrm{Si})$, which were the characteristic elements of the chloroaluminate ionic liquid (Figure 4). Moreover, according to the results of an inductively coupled plasma mass spectrometry (ICP-MS) analysis and nitrogen absorption experiments, the aluminum content and the BET specific surface area of the $\mathrm{Fe}_{3} \mathrm{O}_{4} @ \mathrm{O}_{2} \mathrm{Si}[\mathrm{PrMIM}] \mathrm{Cl} \cdot \mathrm{AlCl}_{3}$ were found to be $1.12 \mathrm{mmol} \mathrm{g}^{-1}$ and $74 \mathrm{~m}^{2} \mathrm{~g}^{-1}$, respectively.

In order to investigate the thermal stability of our catalyst, a thermogravimetric diagram of the $\mathrm{Fe}_{3} \mathrm{O}_{4} @ \mathrm{O}_{2} \mathrm{Si}[\mathrm{PrMIM}] \mathrm{Cl} \cdot \mathrm{AlCl}_{3}$ was recorded by heating the sample up to $600{ }^{\circ} \mathrm{C}$ (Figure 5). The diagram illustrated a slight weight loss of $7 \%$ below $300{ }^{\circ} \mathrm{C}$, owing to the evaporation of adsorbed water. From $320-460{ }^{\circ} \mathrm{C}$, a sharp decrease in weight observed (approximately 15\%) was caused by the decomposition of imidazole moieties [61]. These results did not only confirm the fact that organic parts had been successful grafted on magnetic nanoparticles, but also determined the thermal stability of our catalyst up to $300{ }^{\circ} \mathrm{C}$.

The magnetic parameters of the $\mathrm{Fe}_{3} \mathrm{O}_{4}$ and ionic liquid-coated $\mathrm{Fe}_{3} \mathrm{O}_{4}$ were identified using a vibrating sample magnetometer (VSM) at room temperature (Figure 6). The absence of a hysteresis loop in the obtained VSM curves substantiated our catalyst as a superparamagnetic material. Due to the grafting processes, the saturation magnetization value $\left(M_{s}\right)$ of the $\mathrm{Fe}_{3} \mathrm{O}_{4} @ \mathrm{O}_{2} \mathrm{Si}[\mathrm{PrMIM}] \mathrm{Cl} \cdot \mathrm{AlCl}_{3}(32.64 \mathrm{emu} / \mathrm{g})$ was lower than that of the $\mathrm{Fe}_{3} \mathrm{O}_{4}(34.99 \mathrm{emu} / \mathrm{g})$; however, the $M_{s}$ value of the $\mathrm{Fe}_{3} \mathrm{O}_{4} @ \mathrm{O}_{2} \mathrm{Si}[\mathrm{PrMIM}] \mathrm{Cl} \cdot \mathrm{AlCl}_{3}$ was still high enough for the separation of the catalyst out of the reaction mixture by using an external magnet.

\subsection{Friedel-Crafts Sulfonylation}

In the next experiments, the amount of completed catalyst, $\mathrm{Fe}_{3} \mathrm{O}_{4} @ \mathrm{O}_{2} \mathrm{Si}[\mathrm{PrMIM}] \mathrm{Cl} \cdot \mathrm{AlCl}_{3}$, was investigated in detail to improve the yield of sulfone (entries 3-5, Table 1). Molar ratios of toluene and benzenesulfonyl chloride varying from 1.0:1.0 up to $1.5: 1.0(\mathrm{mmol} / \mathrm{mmol})$ in $0.1 \mathrm{mmol}$ increments for toluene, as well as reaction temperatures in the range of $80-110^{\circ} \mathrm{C}$ in $10^{\circ} \mathrm{C}$ increments were used. Finally, the appropriate amount of toluene $(1.4 \mathrm{mmol})$, benzenesulfonyl chloride $(1.0 \mathrm{mmol})$, and $\mathrm{Fe}_{3} \mathrm{O}_{4} @ \mathrm{O}_{2} \mathrm{Si}[\mathrm{PrMIM}] \mathrm{Cl} \cdot \mathrm{AlCl}_{3}(0.2 \mathrm{~g})$ were selected and used in solvent-free sulfonylation for four hours at $110^{\circ} \mathrm{C}$ (entry 1 , Table 2). 
Further experiments on the nature of alkanesulfonyl/arenesulfonyl chloride were investigated (entries 1-12, Table 2). The results of eight experiments between four arenesulfonyl chlorides and toluene, as well as anisole, displayed that the electron-withdrawing substituents on the aromatic ring of arenesulfonyl chloride caused lower yields of sulfone than electron-donating groups. In addition, three alkanesulfonyl chloride reactions with anisole were also performed; however, the amount of product mixture obtained was much lower than in the case of arenesulfonyl chloride with anisole. In these cases, the sulfonylium cation in transition state stabilized by the aromatic ring better than the aliphatic carbon chain was the main reason for the lower yield of the newborn sulfone obtained from the reactions of three alkanesulfonyl chlorides with anisole (entries 10-12, Table 2). Similarly, in the next series of experiments, $p$-toluenesulfonyl chloride was chosen as the sulfonylating reagent to investigate the influences of the structure of aromatic compounds on the yields of sulfones (entries 13-18, Table 2). Consequently, the Friedel-Crafts sulfonylation preferred the activated aromatic rings to afford the corresponding sulfones in good yields-the more electron-donating substituents on the aromatic ring, the more the yields of sulfones. Therefore, 1-chloro-4-tosylbenzene was formed at a low yield for a longer reaction time (entry 13, Table 2) owing to the chlorine substituent, a deactivated group linked to the benzene ring. With the mild and efficient catalyst, $\mathrm{Fe}_{3} \mathrm{O}_{4} @ \mathrm{O}_{2} \mathrm{Si}[\mathrm{PrMIM}] \mathrm{Cl} \cdot \mathrm{AlCl}_{3}$, demethylation of the methoxy-substituted group was not detected in most experiments by gas chromatographymass spectrometry analyses (GC/MS), as well as thin-layer chromatography (TLC), in comparison with strong Lewis acidic as the aluminum chloride. Selectively, sulfonyl groups were located at the para position with the available substituents on aromatic rings better than those at the ortho position in the Friedel-Crafts sulfonylation of monosubstituted benzene rings. In order to enlarge the scope of substrates used for this process, a polycyclic benzenoid hydrocarbon; e.g., naphthalene or dibenzothiophene, were also selected as model substrates to react with the excess amount of arenesulfonyl chlorides as the reactant and the solvent so that average to fair yields were obtained (entries 20-21, Table 2).

Table 2. The optimized yields of sulfone derivatives from the Friedel-Crafts sulfonylation of activated arene with sulfonyl chlorides catalyzed by $\mathrm{Fe}_{3} \mathrm{O}_{4} @ \mathrm{O}_{2} \mathrm{Si}[\mathrm{PrMIM}] \mathrm{Cl} \cdot \mathrm{AlCl}_{3}{ }^{\text {a }}$.

Entry


Table 2. Cont.

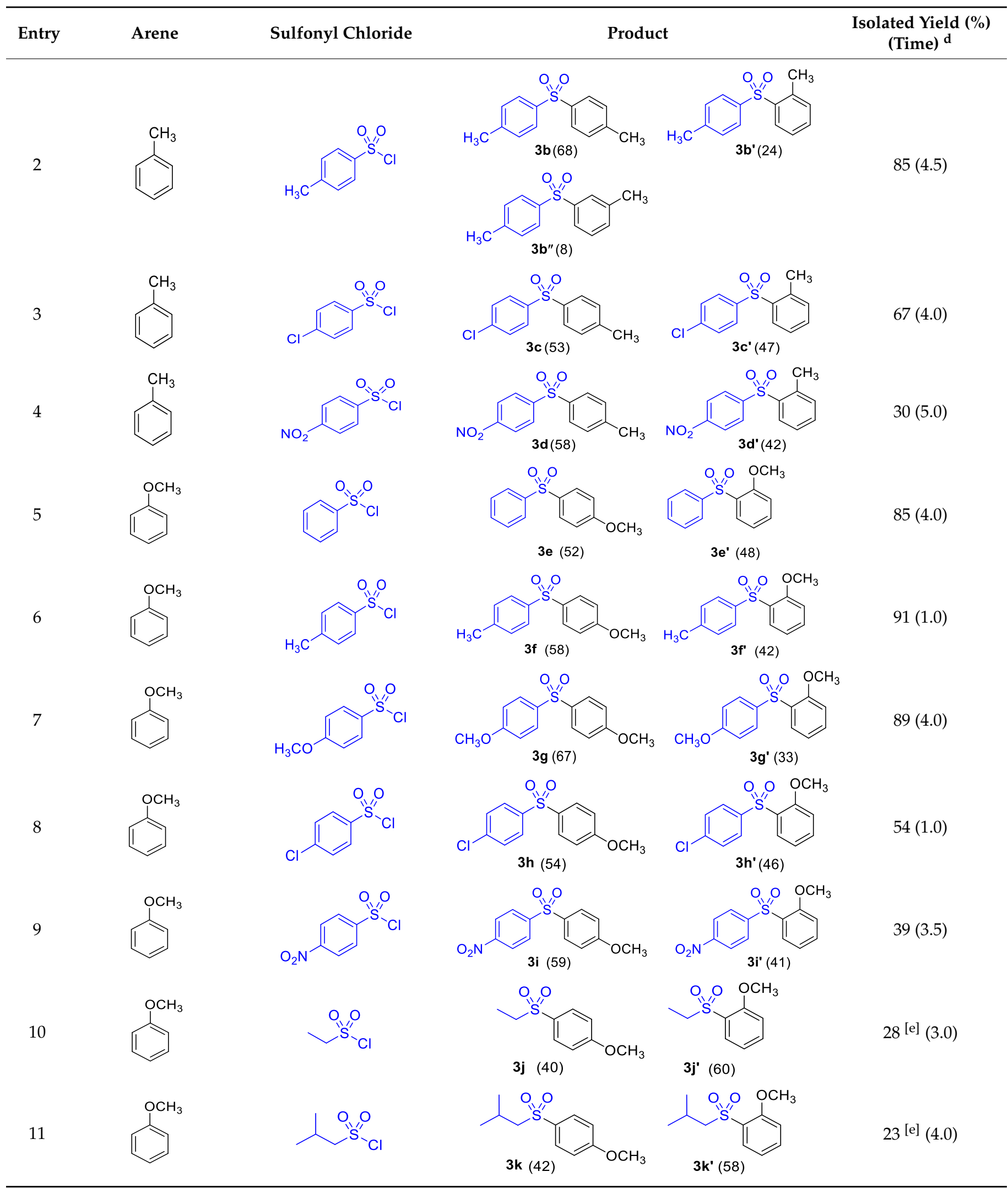


Table 2. Cont.

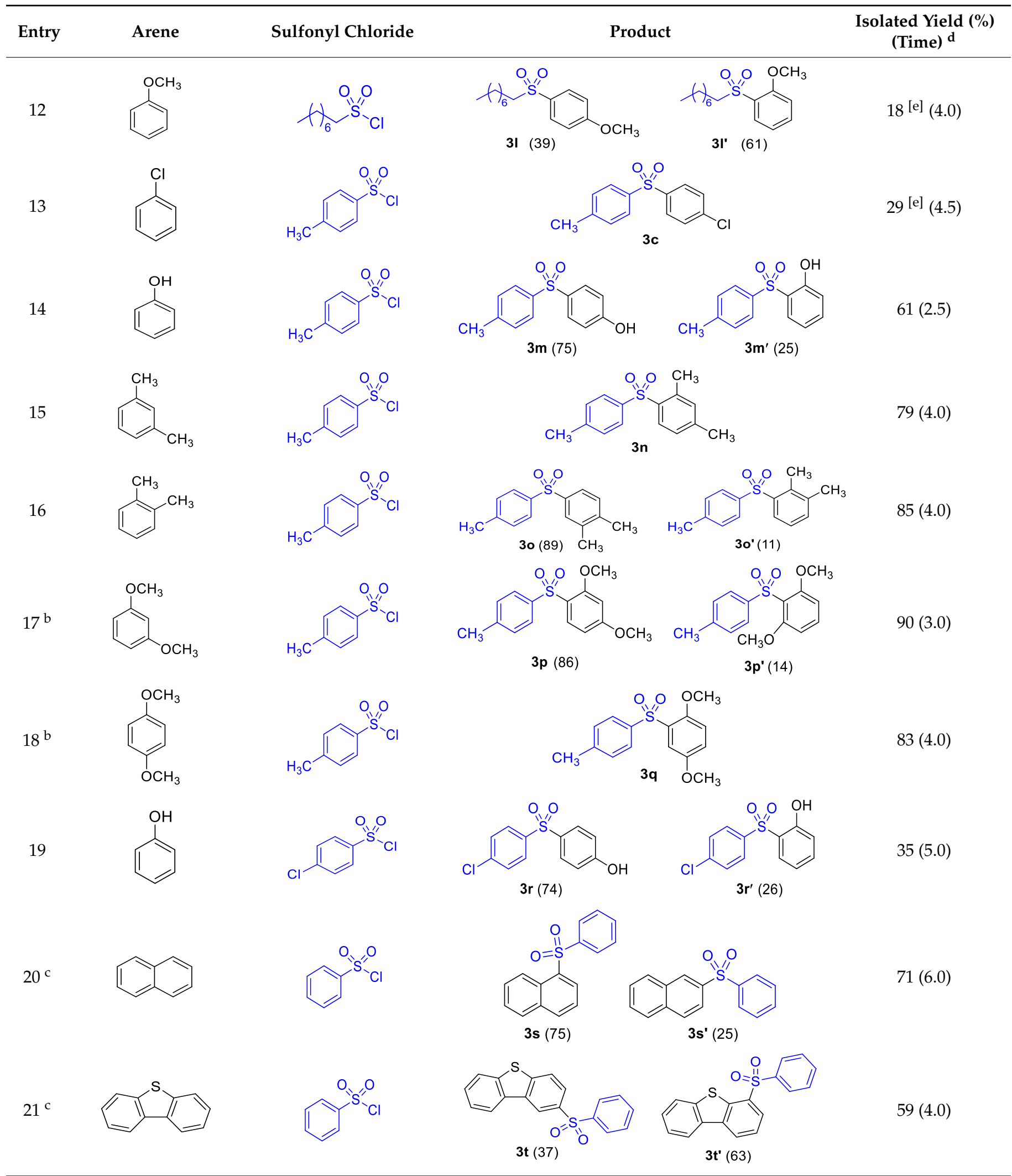

The reactions were performed under the conventional heating method at $110{ }^{\circ} \mathrm{C}$ with ${ }^{\text {a }}$ molar ratio of arene $(1.4 \mathrm{mmol})$ and sulfonyl chloride $(1.0 \mathrm{mmol}),{ }^{\mathrm{b}}$ molar ratio of arene $(1.0 \mathrm{mmol})$ and sulfonyl chloride $(1.0 \mathrm{mmol})$, and ${ }^{\mathrm{c}}$ molar ratio of arene $(1.0 \mathrm{mmol})$ and sulfonyl chloride $(1.4 \mathrm{mmol}){ }^{\mathrm{d}}$ Time in hours. ${ }^{\mathrm{e}}$ Yields were calculated based on the GC/FID analyses. 
In another experiment, the sulfonylating reagent arenesulfonyl chloride was replaced with sulfonic anhydride to produce diaryl sulfones in the Friedel-Crafts sulfonylation of activated aromatic compounds (Table 3). Although the yields of sulfones obtained by using sulfonic anhydride were a little bit lower than those by using sulfonyl chloride, p-toluenesulfonic anhydride showed its capability as a moderately efficient, mild, and alternative reagent for the Friedel-Crafts sulfonylation. Finally, the above results substantiated our choice of $\mathrm{Fe}_{3} \mathrm{O}_{4} @ \mathrm{O}_{2} \mathrm{Si}[\mathrm{PrMIM}] \mathrm{Cl} \cdot \mathrm{AlCl}_{3}$ as the most efficient catalyst for both sulfonylating reagents, sulfonyl chloride and sulfonic anhydride. It not only caused the reaction to occur in mild and solvent-free media, but also improved the isolation of sulfones, as well as the separation of catalyst (Table 3).

Table 3. The optimized yields of sulfone derivatives from the Friedel-Crafts sulfonylation of activated arene with sulfonic anhydride catalyzed by $\mathrm{Fe}_{3} \mathrm{O}_{4} @ \mathrm{O}_{2} \mathrm{Si}[\mathrm{PrMIM}] \mathrm{Cl} \cdot \mathrm{AlCl}_{3}$ a

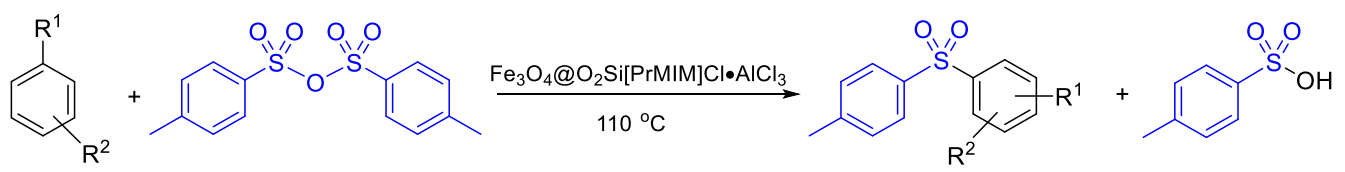

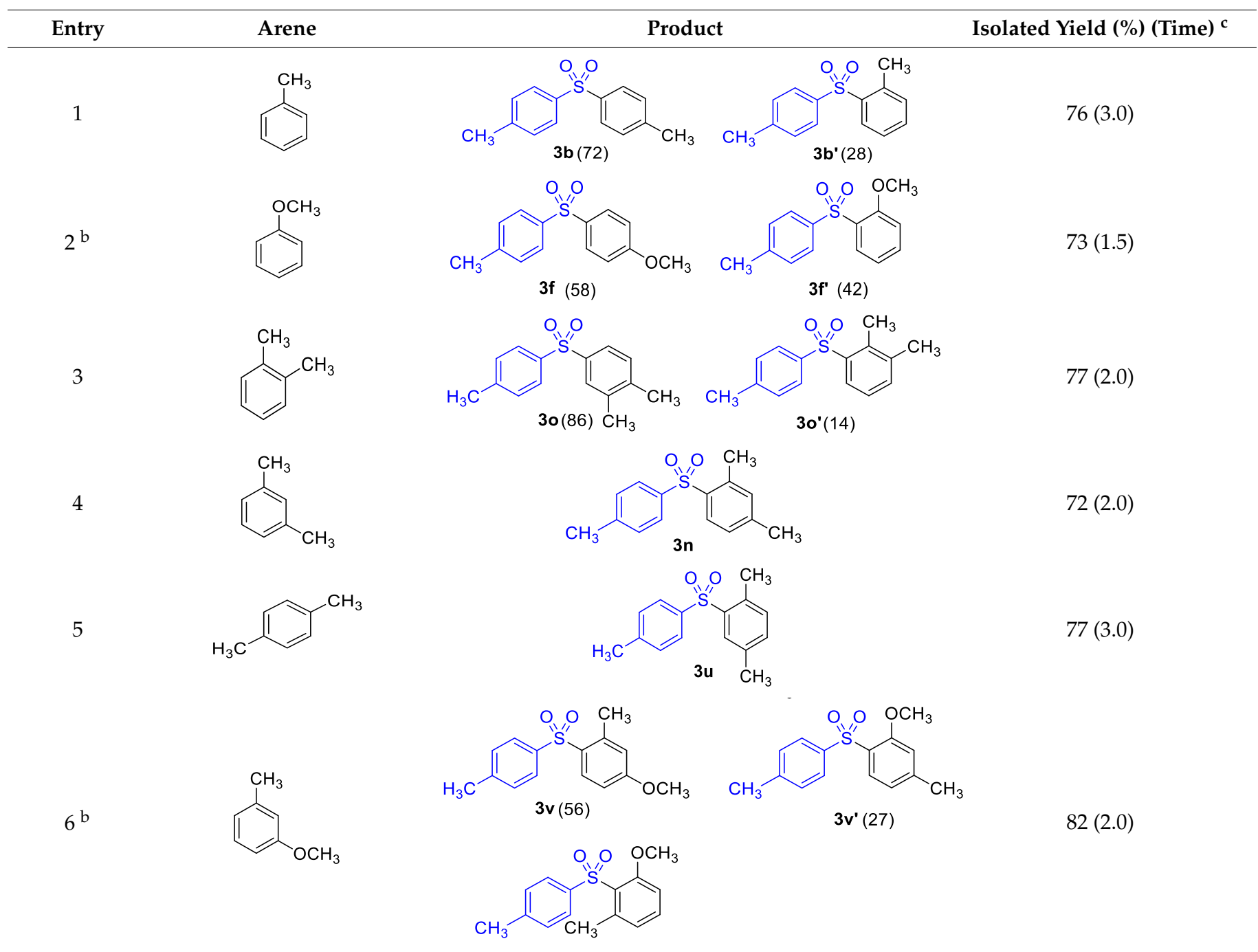


Table 3. Cont.

Entry Isolated Yield (\%) (Time) ${ }^{c}$

The reactions were performed under the conventional heating method at $110{ }^{\circ} \mathrm{C}$ with ${ }^{\text {a }}$ molar ratio of arene $(1.4 \mathrm{mmol})$ and sulfonic anhydride $(1.0 \mathrm{mmol})$ and ${ }^{\mathrm{b}}$ molar ratio of arene $(1.0 \mathrm{mmol})$ and sulfonic anhydride $(1.0 \mathrm{mmol}) .{ }^{\mathrm{c}}$ Time in hours.

With the advantages of $\mathrm{Fe}_{3} \mathrm{O}_{4} @ \mathrm{O}_{2} \mathrm{Si}[\mathrm{PrMIM}] \mathrm{Cl} \cdot \mathrm{AlCl}_{3}$ in the enhancement of reactivity and recovery of catalyst, the reusability of $\mathrm{Fe}_{3} \mathrm{O}_{4} @ \mathrm{O}_{2} \mathrm{Si}[\mathrm{PrMIM}] \mathrm{Cl} \cdot \mathrm{AlCl}_{3}$ was examined. $\mathrm{Fe}_{3} \mathrm{O}_{4} @ \mathrm{O}_{2} \mathrm{Si}[\mathrm{PrMIM}] \mathrm{Cl} \cdot \mathrm{AlCl}_{3}$ was collected after separation with an external magnet, washed alternately with ethanol $(2 \times 5 \mathrm{~mL})$ and acetone $(2 \times 5 \mathrm{~mL})$, and dried in a desiccator overnight. The recovered catalyst was obtained at a yield of $93 \%$ and analyzed by FT-IR. The FT-IR analysis demonstrated that the functional groups of the recovered catalyst in the fourth recycle were compatible with those of the fresh $\mathrm{Fe}_{3} \mathrm{O}_{4} @ \mathrm{O}_{2} \mathrm{Si}[\mathrm{PrMIM}] \mathrm{Cl} \cdot \mathrm{AlCl}_{3}$ (Figure 7). Simultaneously, the recycled $\mathrm{Fe}_{3} \mathrm{O}_{4} @ \mathrm{O}_{2} \mathrm{Si}[\mathrm{PrMIM}] \mathrm{Cl} \cdot \mathrm{AlCl}_{3}$ was used for the sulfonylation of toluene with benzenesulfonyl chloride at $110{ }^{\circ} \mathrm{C}$ for four hours, as in the optimal experiment mentioned in entry 1 of Table 2 . The catalytic efficiency of the $\mathrm{Fe}_{3} \mathrm{O}_{4} @ \mathrm{O}_{2} \mathrm{Si}[\mathrm{PrMIM}] \mathrm{Cl} \cdot \mathrm{AlCl}_{3}$ did not change considerably, even after four cycles of catalyst recovery and reuse (Figure 8 ).

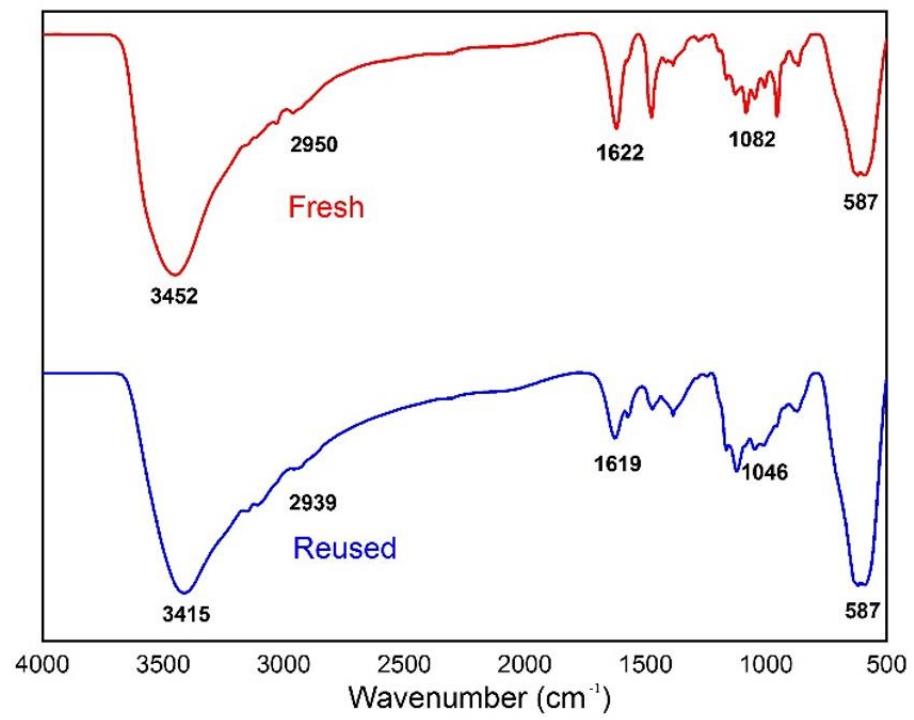

Figure 7. FT-IR spectra of the fresh catalyst and the reused catalyst. 


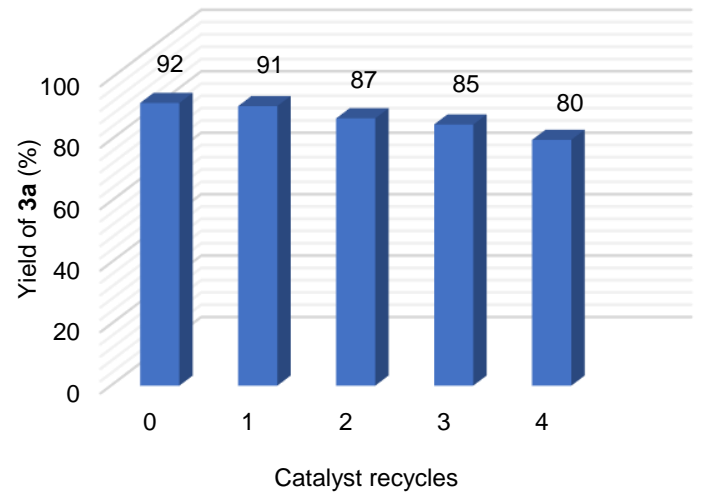

Figure 8. Recycles of $\mathrm{Fe}_{3} \mathrm{O}_{4} @ \mathrm{O}_{2} \mathrm{Si}[\mathrm{PrMIM}] \mathrm{Cl} \cdot \mathrm{AlCl}_{3}$ for the synthesis of phenyl $p$-tolyl sulfone (3a).

The introduced protocol of the sulfone synthesis from the Friedel-Crafts sulfonylation promoted by $\mathrm{Fe}_{3} \mathrm{O}_{4} @ \mathrm{O}_{2} \mathrm{Si}[\mathrm{PrMIM}] \mathrm{Cl} \cdot \mathrm{AlCl}_{3}$ offered several advantages in terms of a lower amount of aromatic compounds used; a green, efficient and economic catalyst; and a high product selectivity and yield under the solvent-free reaction condition compared with the results in the previous literature reported on Friedel-Crafts sulfonylation with different catalysts (Table 4).

Table 4. Comparison of previous methods for Friedel-Crafts sulfonylation of aromatic compounds promoted by several acidic catalysts.

\begin{tabular}{|c|c|c|c|c|c|c|c|c|}
\hline Catalyst & $\mathrm{X}$ & Method & Solvent & $\begin{array}{c}\text { Temp }{ }^{a} \\
\left({ }^{\circ} \mathrm{C}\right)\end{array}$ & Time (h) & $\begin{array}{l}\text { Recyclable } \\
\text { Times }\end{array}$ & $\begin{array}{l}\text { Yield }^{b} \\
(\%)\end{array}$ & Ref. \\
\hline Indium $(0.2 \mathrm{eq})$ & $\mathrm{Cl}$ & Stirring & Dioxane & 100 & $1.5-3.0$ & None & $76-84$ & [28] \\
\hline $\mathrm{Ps}^{-\mathrm{AlCl}_{3}}(0.15 \mathrm{eq})$ & $\mathrm{Cl}$ & Stirring & Arene & 85 & $1.1-2.3$ & 4 & $89-93$ & [35] \\
\hline $\mathrm{SiO}_{2}-\mathrm{AlCl}_{3}(0.1 \mathrm{eq})$ & $\mathrm{Cl}$ & Stirring & Arene & 85 & $1.0-2.0$ & 4 & $91-95$ & [35] \\
\hline $\mathrm{SiO}_{2}-\mathrm{AlCl}_{3}(0.1 \mathrm{eq})$ & $\mathrm{OH}$ & Stirring & None & 80 & $1.3-1.9$ & 4 & $88-94$ & [36] \\
\hline$[\mathrm{BTBA}] \mathrm{FeCl}_{3}(1 \mathrm{eq})$ & $\mathrm{Cl}$ & Stirring & None & 60 & $0.02-0.08$ & None & $90-97$ & [38] \\
\hline $\mathrm{MoO}_{2} \mathrm{Cl}_{2}(20 \mathrm{~mol} \%)$ & $\mathrm{Cl}$ & Reflux & Arene & & 20 & None & $44-89$ & [29] \\
\hline $\mathrm{Cu}(\mathrm{OTf})_{2}, \mathrm{Sn}(\mathrm{OTf})_{2}(5-10 \% \mathrm{~mol})$ & $\mathrm{Cl}$ & Heating & Arene & 120 & $8-12$ & None & $37-98$ & {$[30]$} \\
\hline \multirow{2}{*}{$\begin{array}{c}\mathrm{Fe}(\mathrm{III}) \text {-exchanged } \\
\text { montmorillonite }(0.2 \mathrm{~g})\end{array}$} & $\mathrm{OH}$ & Reflux & Arene & & $6-24$ & None & $60-63$ & \multirow[t]{2}{*}{ [62] } \\
\hline & OTs & Reflux & Arene & & 6.0 & None & $82-94$ & \\
\hline Nafion-H (50 wt \%) & $\mathrm{OH}$ & Reflux & Arene & & $8-20$ & None & $40-82$ & [33] \\
\hline $\mathrm{Fe}(\mathrm{OH})_{3}(0.1 \mathrm{~g})$ & $\mathrm{Cl}$ & Stirring & Arene & $130-160$ & $0.5-3.0$ & None & $74-88$ & [32] \\
\hline $\mathrm{P}_{2} \mathrm{O}_{5} / \mathrm{Al}_{2} \mathrm{O}_{3}(0.67 \mathrm{~g})$ & $\mathrm{OH}$ & Reflux & Arene & & 1.0 & None & $55-90$ & [39] \\
\hline $\mathrm{P}_{2} \mathrm{O}_{5} / \mathrm{SiO}_{2}(1.2 \mathrm{~g})$ & $\mathrm{OH}$ & Reflux & Arene & & $0.5-1.8$ & None & $50-90$ & [40] \\
\hline $\begin{array}{c}\mathrm{Fe}_{3} \mathrm{O}_{4} @ \mathrm{O}_{2} \mathrm{Si}[\mathrm{PrMIM}] \mathrm{Cl} \cdot \mathrm{AlCl}_{3} \\
(0.2 \mathrm{~g})\end{array}$ & $\mathrm{Cl}$ & Heating & None & 110 & $1.0-5.0$ & 4 & $30-92$ & [Our work] \\
\hline
\end{tabular}

a Temperature $\left({ }^{\circ} \mathrm{C}\right) ;{ }^{b}$ isolated yield.

\section{Materials and Methods}

Sulfonyl chlorides (benzenesulfonyl chloride, 4-methylbenzenesulfonyl chloride, ethanesulfonyl chloride, isobutanesulfonyl chloride, ... ), anhydrous aluminum chloride, arenes (anisole, 1,3-dimethoxybenzene, naphthalene, chlorobenzene, ... ), (3-chloropropyl)trimethoxysilane, and 1-methylimidazole were from Sigma-Aldrich (Darmstadt, Germany), and the $p$-toluenesulfonic anhydride and isomer of xylene were from Acros. All commercially available chemicals were analyzed for authenticity and purity by GC/MS before being used. X-ray diffraction patterns were measured on a Brüker D8 Advance diffractometer. 
Fourier-transform infrared (FT-IR) spectra were recorded on a Brüker E400 spectrometer in the range of $4000-500 \mathrm{~cm}^{-1}$. Thermal gravimetric analysis (TGA) was performed using a TA Instruments Q-500 thermal gravimetric analyzer. Magnetic properties were measured using an ID-EV 11 vibrating sample magnetometer (VSM). Size and structure of materials were obtained using a Hitachi S- 4800 scanning electron microscope (SEM) and JOEL JEM1010 transmission electron microscope (TEM). The composition of the catalyst was analyzed by energy-dispersive X-ray spectroscopy (EDX) on a Shimadzu EDX-8000. The specific surface area was determined using the Brunauer-Emmett-Teller (BET) technique with a Quantachrome NOVA 2200e analyzer (Boynton Beach, FL, USA). Inductively coupled plasma mass spectroscopy (ICP-MS) data were recorded on an Agilent 7700s instrument. NMR spectra were recorded on a Brüker AVANCE 500 or Brüker AVANCE NEO 400 at 500 or $400 \mathrm{MHz}$ for ${ }^{1} \mathrm{H}-\mathrm{NMR}$ and 125 or $100 \mathrm{MHz}$ for ${ }^{13} \mathrm{C}-\mathrm{NMR}$. Gas chromatography analyses were performed on an Agilent 6890, with a flame ionization detector equipped with a J and W DB-5MS capillary column ( $30 \mathrm{~m}, 0.25 \mathrm{~mm}$ i.d., $0.25 \mu \mathrm{m}$ film thickness). Gas chromatography-mass spectrometry (GC-MS) measurements were carried out on an Agilent GC System 7890 equipped with a mass selective detector (Agilent 5973N) and a capillary DB-5MS column $(30 \mathrm{~m} \times 250 \mu \mathrm{m} \times 0.25 \mu \mathrm{m})$. High-resolution mass spectrometry (HRMS) was recorded on an Agilent 1200 series high-performance liquid chromatograph with a Bruker micrOTOF-QII EIS mass spectrometer detector.

\subsection{General Procedure for Preparation of Heterogeneous Catalyst $\mathrm{Fe}_{3} \mathrm{O}_{4} @ \mathrm{O}_{2} \mathrm{Si}[\mathrm{PrMIM}] \mathrm{Cl} \cdot \mathrm{AlCl}_{3}$}

3.1.1. The Preparation of MNPs via the Modified Chemical Coprecipitation Method

Typically, $100 \mathrm{~mL}$ of $\mathrm{FeSO}_{4} \cdot 7 \mathrm{H}_{2} \mathrm{O}(6.0 \mathrm{mmol}, 1.668 \mathrm{~g})$ and $\mathrm{Fe}\left(\mathrm{NO}_{3}\right)_{3} \cdot 9 \mathrm{H}_{2} \mathrm{O}(12.0 \mathrm{mmol}$, $4.848 \mathrm{~g}$ ) dissolved completely in $100 \mathrm{~mL}$ distilled water was dropped slowly into a $500 \mathrm{~mL}$ beaker containing $200 \mathrm{~mL}$ of $0.25 \mathrm{M} \mathrm{NaOH}$ solution within $1 \mathrm{~h}$ at $80^{\circ} \mathrm{C}$ under vigorous mechanical stirring at $500 \mathrm{rpm}$. The black precipitate was washed with distilled water $(2 \times 100 \mathrm{~mL})$ until reaching $\mathrm{pH} 7$ and dried at $150{ }^{\circ} \mathrm{C}$ for $4 \mathrm{~h}$. The crude iron oxide particles were ground with a porcelain mortar to obtain the fine magnetic nanoparticles (MNPs) [56].

3.1.2. The Preparation of 3-Methyl-1-(3-trimethoxysilylpropyl)-1H-imidazole-3-ium Chloride

A mixture of (3-chloropropyl)trimethoxysilane ( $20.0 \mathrm{mmol}, 3.974 \mathrm{~g}$ ) and 1-methylimidazole $(20.0 \mathrm{mmol}, 1.642 \mathrm{~g})$ in a round-bottom $25 \mathrm{~mL}$ flask was stirred at $80^{\circ} \mathrm{C}$ for $72 \mathrm{~h}$. After reaction completion, the mixture of products was washed with diethyl ether $(3 \times 5 \mathrm{~mL})$. Subsequently, the pure ionic liquid with light yellow, 3-methyl-1-(3-trimethoxysilylpropyl)$1 \mathrm{H}$-imidazole-3-ium chloride obtained after the solvent removal under vacuum pressure was identified by ${ }^{1} \mathrm{H}$ and ${ }^{13} \mathrm{C}$ NMR spectroscopy. These spectra were compatible with the previous literature [56].

\subsubsection{Methyl-1-(3-trimethoxysilylpropyl)-1H-imidazole-3-ium Chloride}

Methyl-1-(3-trimethoxysilylpropyl)-1H-imidazole-3-ium chloride, light yellow liquid. ${ }^{1} \mathrm{H}$ NMR (500 MHz, CDCl $)$ : $\delta(\mathrm{ppm}) 10.56(\mathrm{brs}, 1 \mathrm{H}), 7.46(\mathrm{~s}, 1 \mathrm{H}), 7.32(\mathrm{~s}, 1 \mathrm{H}), 4.29(\mathrm{t}$, $J=7.5 \mathrm{~Hz}, 2 \mathrm{H}), 4.09(\mathrm{~s}, 3 \mathrm{H}), 3.54(\mathrm{~s}, 9 \mathrm{H}), 1.98(\mathrm{p}, J=7.5 \mathrm{~Hz}, 2 \mathrm{H}), 0.63-0.59(\mathrm{~m}, 2 \mathrm{H}) .{ }^{13} \mathrm{C}$ NMR (125 MHz, $\mathrm{CDCl}_{3}$ ): $\delta$ (ppm) 138.5, 123.3, 121.8, 51.9, 50.8, 36.8, 24.2, 6.1.

\subsubsection{The Preparation of $\mathrm{Fe}_{3} \mathrm{O}_{4} @ \mathrm{O}_{2} \mathrm{Si}[\mathrm{PrMIM}] \mathrm{Cl}$}

$\mathrm{Fe}_{3} \mathrm{O}_{4}$ nanoparticles (1.0 mmol, $0.232 \mathrm{~g}$ ), 3-methyl-1-(3-trimethoxysilylpropyl)-1Himidazole-3-ium chloride $(2.0 \mathrm{mmol}, 0.562 \mathrm{~g})$, absolute ethanol $(5.0 \mathrm{~mL})$, and $28 \%$ ammonia solution $(0.2 \mathrm{~mL})$ were added into a round-bottom $25 \mathrm{~mL}$ flask and stirred at room temperature for $24 \mathrm{~h}$. After reaction completion, $\mathrm{Fe}_{3} \mathrm{O}_{4} @ \mathrm{O}_{2} \mathrm{Si}[\mathrm{PrMIM}] \mathrm{Cl}$, a dark-brown solid, was washed with ethanol $(2 \times 5 \mathrm{~mL})$ and collected with an external magnet and then dried under vacuum. 


\subsubsection{The Preparation of $\mathrm{Fe}_{3} \mathrm{O}_{4} @ \mathrm{O}_{2} \mathrm{Si}[\mathrm{PrMIM}] \mathrm{Cl} \cdot \mathrm{AlCl}_{3}$}

Anhydrous aluminum chloride, $\mathrm{AlCl}_{3}(4.0 \mathrm{mmol}, 0.533 \mathrm{~g})$, was added slowly into a $25 \mathrm{~mL}$ round-bottom flask containing $\mathrm{Fe}_{3} \mathrm{O}_{4} @ \mathrm{O}_{2} \mathrm{Si}[\mathrm{PrMIM}] \mathrm{Cl}$ dispersed in $5 \mathrm{~mL}$ of absolute ethanol. The mixture was stirred at room temperature for $12 \mathrm{~h}$. After that, the catalyst of $\mathrm{Fe}_{3} \mathrm{O}_{4} @ \mathrm{O}_{2} \mathrm{Si}[\mathrm{PrMIM}] \mathrm{Cl} \cdot \mathrm{AlCl}_{3}$ was washed with ethanol $(2 \times 5 \mathrm{~mL})$ and put into the desiccator overnight. The dark-brown solid obtained was ground into a homogeneous fine powder and stored in the desiccator before using.

\subsection{General Procedure for the Friedel-Crafts Sulfonylation}

The aromatic compound $(1.0 \mathrm{mmol})$, sulfonyl chloride/sulfonic anhydride $(1.0 \mathrm{mmol}$, and $\mathrm{Fe}_{3} \mathrm{O}_{4} @ \mathrm{O}_{2} \mathrm{Si}[\mathrm{PrMIM}] \mathrm{Cl} \cdot \mathrm{AlCl}_{3}(0.2 \mathrm{~g})$ were added into a $5 \mathrm{~mL}$ round-bottom flask assembled with the condenser. The reaction mixture was heated at $110^{\circ} \mathrm{C}$ for a specific period of time. After cooling down, the mixture of products was extracted with ethyl acetate $(4 \times 5 \mathrm{~mL})$, and the solid catalyst was collected by using a magnetic bar. The organic phase was rinsed with water $(2 \times 10 \mathrm{~mL})$ and dried with anhydrous $\mathrm{Na}_{2} \mathrm{SO}_{4}$. After that, the removal of the solvent by rotary evaporation was performed to obtain the crude product. The product was purified by column chromatography using eluent as a mixture of $n$-hexane and ethyl acetate $(8: 2 v / v)$.

\subsection{Spectroscopic Data}

The identification and purity of all products reported were determined by ${ }^{1} \mathrm{H}-\mathrm{NMR}$,

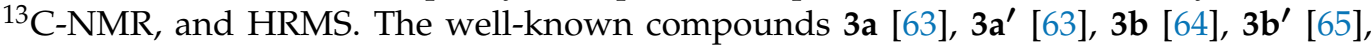

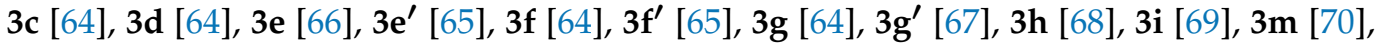
$3 \mathbf{m}^{\prime}$ [71], 3n [32], 3o [70], 3s [30], and 3u [62] were found to be compatible with the previous literature. The unknown products are described below (Figure S2).

1-((4-Chlorophenyl)sulfonyl)-2-methylbenzene (3c'): White solid; m.p.: $137-138{ }^{\circ} \mathrm{C}$. ${ }^{1} \mathrm{H}$ NMR $\left(500 \mathrm{MHz}, \mathrm{CDCl}_{3}\right) \delta(\mathrm{ppm}) 8.19(\mathrm{dd}, J=8.0 \mathrm{~Hz}, J=1.5 \mathrm{~Hz}, 1 \mathrm{H}), 7.81-7.78(\mathrm{~m}$, $2 \mathrm{H}), 7.51-7.46(\mathrm{~m}, 3 \mathrm{H}), 7.40(\mathrm{t}, J=7.5 \mathrm{~Hz}, 1 \mathrm{H}), 7.24(\mathrm{~d}, J=7.5 \mathrm{~Hz}, 1 \mathrm{H}), 2.44(\mathrm{~s}, 3 \mathrm{H}) .{ }^{13} \mathrm{C}$ NMR (125 MHz, CDCl $\left.)_{3}\right): \delta$ (ppm) 140.0, 139.8, 138.7, 138.1, 134.0, 132.9, 129.6, 129.5, 129.3, 126.8, 20.4. HRMS-ESI: $\mathrm{m} / z$ [M $+\mathrm{Na}]^{+}$calcd. for $\mathrm{C}_{13} \mathrm{H}_{11} \mathrm{O}_{2} \mathrm{SCl}$, 289.0066; found, 289.0101 (Figure S3).

1-Methyl-2-((4-nitrophenyl)sulfonyl)benzene (3d'): White solid; m.p.: $106-108{ }^{\circ} \mathrm{C}$. ${ }^{1} \mathrm{H}$ NMR $\left(500 \mathrm{MHz}, \mathrm{CDCl}_{3}\right): \delta(\mathrm{ppm}) 8.35-8.33(\mathrm{~m}, 2 \mathrm{H}), 8.25(\mathrm{dd}, J=7.5 \mathrm{~Hz}, J=1.0 \mathrm{~Hz}$, $1 \mathrm{H}), 8.05-8.03(\mathrm{~m}, 2 \mathrm{H}), 7.55(\mathrm{td}, J=7.5 \mathrm{~Hz}, J=1.5 \mathrm{~Hz}, 1 \mathrm{H}), 7.46(\mathrm{t}, J=7.5 \mathrm{~Hz}, 1 \mathrm{H}), 7.28$ $(\mathrm{d}, J=7.5 \mathrm{~Hz}, 1 \mathrm{H}), 2.44(\mathrm{~s}, 3 \mathrm{H}) .{ }^{13} \mathrm{C} \mathrm{NMR}\left(125 \mathrm{MHz}, \mathrm{CDCl}_{3}\right): \delta(\mathrm{ppm}) 150.5,147.3,138.4$, 137.6, 134.7, 133.2, 130.0, 129.1, 127.1, 124.5, 20.4. HRMS-ESI: $m / z[\mathrm{M}+\mathrm{Na}]^{+}$calcd. for $\mathrm{C}_{13} \mathrm{H}_{11} \mathrm{NO}_{4} \mathrm{~S}$, 300.0377; found, 300.0321.

1-((4-Chlorophenyl)sulfonyl)-2-methoxybenzene (3h'): White solid; m.p.: $139-141{ }^{\circ} \mathrm{C}$. ${ }^{1} \mathrm{H} \mathrm{NMR}\left(500 \mathrm{MHz}, \mathrm{CDCl}_{3}\right): \delta(\mathrm{ppm}) 8.14(\mathrm{dd}, J=8.0 \mathrm{~Hz}, J=1.5 \mathrm{~Hz}, 1 \mathrm{H}), 7.90(\mathrm{~d}, J=8.5 \mathrm{~Hz}$, $2 \mathrm{H}), 7.57-7.54(\mathrm{~m}, 1 \mathrm{H}), 7.45(\mathrm{~d}, J=8.5 \mathrm{~Hz}, 2 \mathrm{H}), 7.11(\mathrm{t}, J=7.5 \mathrm{~Hz}, 1 \mathrm{H}), 6.91(\mathrm{~d}, J=7.5 \mathrm{~Hz}$, 1H), 3.78 (s, 3H). $\left.{ }^{13} \mathrm{C} \mathrm{NMR} \mathrm{(125} \mathrm{MHz,} \mathrm{CDCl}_{3}\right): \delta$ (ppm) 157.2, 140.3, 139.7, 135.9, 130.1, 130.0, $128.9,128.8,120.8,112.7,56.1$. HRMS-ESI: $m / z[\mathrm{M}+\mathrm{Na}]^{+}$calcd. for $\mathrm{C}_{13} \mathrm{H}_{11} \mathrm{O}_{3} \mathrm{SCl}$, 305.0015; found, 305.0004.

1-Methoxy-2-((4-nitrophenyl)sulfonyl)benzene (3i'): White solid; m.p.: $164-165^{\circ} \mathrm{C}$. ${ }^{1} \mathrm{H}$ NMR $\left(500 \mathrm{MHz}, \mathrm{CDCl}_{3}\right): \delta(\mathrm{ppm})$ 8.33-8.31 (m, 2H), 8.18-8.14 (m, 3H), 7.61-7.59 (m, $1 \mathrm{H}), 7.18-7.14(\mathrm{~m}, 1 \mathrm{H}), 6.93(\mathrm{~d}, J=8.0 \mathrm{~Hz}, 1 \mathrm{H}), 3.78(\mathrm{~s}, 3 \mathrm{H}) .{ }^{13} \mathrm{C}$ NMR $\left(125 \mathrm{MHz}, \mathrm{CDCl}_{3}\right)$ : $\delta$ (ppm) 157.3, 147.5, 136.6, 130.3, 129.9, 128.8, 123.9, 121.1, 115.1, 112.8, 56.2. HRMS-ESI: $m / z[\mathrm{M}+\mathrm{Na}]^{+}$calcd. for $\mathrm{C}_{13} \mathrm{H}_{11} \mathrm{O}_{5} \mathrm{SN}, 316.0256$; found, 316.0223 .

1-(Ethylsulfonyl)-4-methoxybenzene (3j): White solid; m.p.: $56-58{ }^{\circ} \mathrm{C} .{ }^{1} \mathrm{H}$ NMR $\left(500 \mathrm{MHz}, \mathrm{CDCl}_{3}\right): \delta(\mathrm{ppm}) 7.83(\mathrm{~d}, J=9.0 \mathrm{~Hz}, 2 \mathrm{H}), 7.02(\mathrm{~d}, J=9.0 \mathrm{~Hz}, 2 \mathrm{H}), 3.89(\mathrm{~s}, 3 \mathrm{H})$, $3.08(\mathrm{q}, J=7.5 \mathrm{~Hz}, 2 \mathrm{H}), 1.26(\mathrm{t}, J=7.5 \mathrm{~Hz}, 3 \mathrm{H}) .{ }^{13} \mathrm{C} \mathrm{NMR}\left(125 \mathrm{MHz}, \mathrm{CDCl}_{3}\right): \delta(\mathrm{ppm}) 163.9$, 130.5, 130.4, 114.6, 55.8, 51.0, 7.7. HRMS-ESI: $m / z[\mathrm{M}+\mathrm{H}]^{+}$calcd. for $\mathrm{C}_{9} \mathrm{H}_{12} \mathrm{O}_{3} \mathrm{~S}, 201.0585$; found, 201.0585 . 
1-(Ethylsulfonyl)-2-methoxybenzene $\left(\mathbf{3 j}^{\prime}\right)$ : White solid; m.p.: $88-90{ }^{\circ} \mathrm{C} .{ }^{1} \mathrm{H}$ NMR $\left(500 \mathrm{MHz}, \mathrm{CDCl}_{3}\right): \delta(\mathrm{ppm}) 7.96(\mathrm{dd}, J=8.0 \mathrm{~Hz}, J=2.0 \mathrm{~Hz}, 1 \mathrm{H}), 7.61-7.57(\mathrm{~m}, 1 \mathrm{H}), 7.12-7.09$ $(\mathrm{m}, 1 \mathrm{H}), 7.04(\mathrm{~d}, J=8.5 \mathrm{~Hz}, 1 \mathrm{H}), 3.98(\mathrm{~s}, 3 \mathrm{H}), 3.37(\mathrm{q}, J=7.5 \mathrm{~Hz}, 2 \mathrm{H}), 1.24(\mathrm{t}, J=7.5 \mathrm{~Hz}, 3 \mathrm{H})$. ${ }^{13} \mathrm{C} \mathrm{NMR}\left(125 \mathrm{MHz}, \mathrm{CDCl}_{3}\right): \delta$ (ppm) 157.4, 135.5, 130.9, 126.4, 120.8, 112.3, 56.3, 48.7, 7.1. HRMS-ESI: $m / z[M+H]^{+}$calcd. for $\mathrm{C}_{9} \mathrm{H}_{12} \mathrm{O}_{3} \mathrm{~S}, 201.0585$; found, 201.0583.

1-(Isobutylsulfonyl)-4-methoxybenzene (3k): Light brown liquid. ${ }^{1} \mathrm{H} \mathrm{NMR}(500 \mathrm{MHz}$, $\left.\mathrm{CDCl}_{3}\right): \delta(\mathrm{ppm}) 7.84(\mathrm{~d}, J=9.0 \mathrm{~Hz}, 2 \mathrm{H}), 7.01(\mathrm{~d}, J=9.0 \mathrm{~Hz}, 2 \mathrm{H}), 3.88(\mathrm{~s}, 3 \mathrm{H}), 2.96(\mathrm{~d}$, $J=6.5 \mathrm{~Hz}, 2 \mathrm{H}), 2.21-2.17(\mathrm{~m}, 1 \mathrm{H}), 1.04(\mathrm{~d}, J=6.5 \mathrm{~Hz}, 6 \mathrm{H}) .{ }^{13} \mathrm{C} \mathrm{NMR}\left(125 \mathrm{MHz}, \mathrm{CDCl}_{3}\right)$ : $\delta$ (ppm) 163.8, 132.0, 130.2, 114.6, 64.5, 55.8, 24.3, 22.9. HRMS-ESI: $m / z[\mathrm{M}+\mathrm{H}]^{+}$calcd. for $\mathrm{C}_{11} \mathrm{H}_{16} \mathrm{O}_{3} \mathrm{~S}, 229.0898$; found, 229.0896.

1-(Isobutylsulfonyl)-2-methoxybenzene (3k'): Light brown liquid. ${ }^{1} \mathrm{H}$ NMR $(500 \mathrm{MHz}$, $\left.\mathrm{CDCl}_{3}\right): \delta(\mathrm{ppm}) 7.97(\mathrm{dd}, J=8.0 \mathrm{~Hz}, J=2.0 \mathrm{~Hz}, 1 \mathrm{H}), 7.60-7.56(\mathrm{~m}, 1 \mathrm{H}), 7.10(\mathrm{td}, J=7.5 \mathrm{~Hz}$, $J=1.0 \mathrm{~Hz}, 1 \mathrm{H}), 7.04(\mathrm{~d}, J=8.5 \mathrm{~Hz}, 1 \mathrm{H}), 3.98(\mathrm{~s}, 3 \mathrm{H}), 3.25(\mathrm{~d}, J=6.5 \mathrm{~Hz}, 2 \mathrm{H}), 2.23-2.18(\mathrm{~m}$, $1 \mathrm{H}), 1.03(\mathrm{~d}, J=6.5 \mathrm{~Hz}, 6 \mathrm{H}) .{ }^{13} \mathrm{C}$ NMR $\left(125 \mathrm{MHz}, \mathrm{CDCl}_{3}\right): \delta(\mathrm{ppm}) 157.3,135.4,130.3,128.1$, $120.8,112.3,62.3,56.3,24.1,22.7$. HRMS-ESI: $m / z[\mathrm{M}+\mathrm{H}]^{+}$calcd. for $\mathrm{C}_{11} \mathrm{H}_{16} \mathrm{O}_{3} \mathrm{~S}, 229.0898$; found, 229.0896 .

1-Methoxy-4-(octylsulfonyl)benzene (31): Light brown liquid. ${ }^{1} \mathrm{H}$ NMR $(500 \mathrm{MHz}$, $\left.\mathrm{CDCl}_{3}\right): \delta(\mathrm{ppm}) 7.84-7.81(\mathrm{~m}, 2 \mathrm{H}), 7.03-7.00(\mathrm{~m}, 2 \mathrm{H}), 3.88(\mathrm{~s}, 3 \mathrm{H}), 3.06-3.03(\mathrm{~m}, 2 \mathrm{H})$, 1.70-1.67 (m, 2H), 1.35-1.32 (m, 2H), 1.27-1.23 (m, 8H), $0.86(\mathrm{t}, J=7.0 \mathrm{~Hz}, 3 \mathrm{H}) .{ }^{13} \mathrm{C} \mathrm{NMR}$ $\left(125 \mathrm{MHz}_{\mathrm{CDCl}}\right.$ ): $\delta$ (ppm) 163.8, 131.1, 130.4, 114.6, 56.8, 55.8, 31.8, 29.1, 29.0, 28.4, 23.0, 22.7, 14.2. HRMS-ESI: $m / z[\mathrm{M}+\mathrm{H}]^{+}$calcd. for $\mathrm{C}_{15} \mathrm{H}_{24} \mathrm{O}_{3} \mathrm{~S}, 285.1524$; found, 285.1522 .

1-Methoxy-2-(octylsulfonyl)benzene (31'): Light brown liquid. ${ }^{1} \mathrm{H}$ NMR $(500 \mathrm{MHz}$, $\left.\mathrm{CDCl}_{3}\right): \delta(\mathrm{ppm}) 7.96(\mathrm{dd}, J=8.0 \mathrm{~Hz}, J=2.0 \mathrm{~Hz}, 1 \mathrm{H}), 7.59-7.57(\mathrm{~m}, 1 \mathrm{H}), 7.10(\mathrm{td}, J=7.5 \mathrm{~Hz}$, $J=1.0 \mathrm{~Hz}, 1 \mathrm{H}), 7.05(\mathrm{~d}, J=8.5 \mathrm{~Hz}, 1 \mathrm{H}), 3.98(\mathrm{~s}, 3 \mathrm{H}), 3.35-3.32(\mathrm{~m}, 2 \mathrm{H}), 1.69-1.66(\mathrm{~m}, 2 \mathrm{H})$, $1.37-1.33(\mathrm{~m}, 2 \mathrm{H}), 1.28-1.23(\mathrm{~m}, 8 \mathrm{H}), 0.86(\mathrm{t}, J=7.0 \mathrm{~Hz}, 3 \mathrm{H}) .{ }^{13} \mathrm{C}$ NMR $\left(125 \mathrm{MHz}, \mathrm{CDCl}_{3}\right): \delta$ (ppm) 157.5, 135.5, 130.8, 129.2, 120.9, 112.4, 56.4, 54.6, 31.8, 29.1, 29.0, 28.4, 22.7, 22.5, 14.2. HRMS-ESI: $m / z[\mathrm{M}+\mathrm{H}]^{+}$calcd. for $\mathrm{C}_{15} \mathrm{H}_{24} \mathrm{O}_{3} \mathrm{~S}$, 285.1524; found: 285.1524 .

2,3-Dimethyl-1-tosylbenzene (3o'): White solid; m.p.: $130-132{ }^{\circ} \mathrm{C} .{ }^{1} \mathrm{H} \mathrm{NMR}(500 \mathrm{MHz}$, $\left.\mathrm{CDCl}_{3}\right): \delta(\mathrm{ppm}) 8.07(\mathrm{~d}, J=8.0 \mathrm{~Hz}, 1 \mathrm{H}), 7.73(\mathrm{~d}, J=8.5 \mathrm{~Hz}, 2 \mathrm{H}), 7.37(\mathrm{~d}, J=7.5 \mathrm{~Hz}, 1 \mathrm{H})$, 7.29-7.27 (m, 3H), $2.41(\mathrm{~s}, 3 \mathrm{H}), 2.35(\mathrm{~s}, 3 \mathrm{H}), 2.26(\mathrm{~s}, 3 \mathrm{H}) .{ }^{13} \mathrm{C}$ NMR $\left(125 \mathrm{MHz}, \mathrm{CDCl}_{3}\right)$ : $\delta$ (ppm) 143.9, 139.7, 139.5, 139.0, 136.4, 135.2, 129.8, 127.8, 127.5, 125.9, 21.7, 20.5, 16.1. HRMS-ESI: $m / z[\mathrm{M}+\mathrm{H}]^{+}$calcd. for $\mathrm{C}_{15} \mathrm{H}_{16} \mathrm{O}_{2} \mathrm{~S}, 261.0949$; found, 261.0954 .

2,4-Dimethoxy-1-tosylbenzene (3p): White solid; m.p.: $159-161{ }^{\circ} \mathrm{C} .{ }^{1} \mathrm{H} \mathrm{NMR}(500 \mathrm{MHz}$, $\left.\mathrm{CDCl}_{3}\right): \delta(\mathrm{ppm}) 8.04(\mathrm{~d}, J=8.5 \mathrm{~Hz}, 1 \mathrm{H}), 7.80(\mathrm{~d}, J=8.5 \mathrm{~Hz}, 2 \mathrm{H}), 7.23(\mathrm{~d}, J=8.0 \mathrm{~Hz}, 2 \mathrm{H})$, $6.55(\mathrm{dd}, J=8.5 \mathrm{~Hz}, J=2.0 \mathrm{~Hz}, 1 \mathrm{H}), 6.36(\mathrm{~d}, J=2.0 \mathrm{~Hz}, 1 \mathrm{H}), 3.81(\mathrm{~s}, 3 \mathrm{H}), 3.72(\mathrm{~s}, 3 \mathrm{H}), 2.38$ (s, 3H). ${ }^{13} \mathrm{C}$ NMR $\left(125 \mathrm{MHz}, \mathrm{CDCl}_{3}\right): \delta$ (ppm) 165.6, 158.7, 143.5, 139.4, 131.7, 129.2, 128.3, 121.9, 104.7, 99.6, 56.0, 55.8, 21.7. HRMS-ESI: $m / z[\mathrm{M}+\mathrm{Na}]^{+}$calcd. for $\mathrm{C}_{15} \mathrm{H}_{16} \mathrm{O}_{4} \mathrm{~S}, 315.0667$; found, 315.0632 .

1,3-Dimethoxy-2-tosylbenzene (3p'): White solid; m.p.: $104-106{ }^{\circ} \mathrm{C} .{ }^{1} \mathrm{H} \mathrm{NMR}(500 \mathrm{MHz}$, $\left.\mathrm{CDCl}_{3}\right): \delta(\mathrm{ppm}) 7.84(\mathrm{~d}, J=8.0 \mathrm{~Hz}, 2 \mathrm{H}), 7.37(\mathrm{t}, J=8.5 \mathrm{~Hz}, 1 \mathrm{H}), 7.24(\mathrm{~d}, J=8.0 \mathrm{~Hz}, 2 \mathrm{H}), 6.54$ $(\mathrm{d}, J=8.5 \mathrm{~Hz}, 2 \mathrm{H}), 3.77(\mathrm{~s}, 6 \mathrm{H}), 2.39$ (s, 3H). ${ }^{13} \mathrm{C} \mathrm{NMR}\left(125 \mathrm{MHz}, \mathrm{CDCl}_{3}\right): \delta$ (ppm) 159.5, 143.0, 141.7, 134.8, 130.9, 128.8, 127.4, 118.4, 105.4, 56.5, 21.5. HRMS-ESI: $m / z$ [M + Na] ${ }^{+}$ calcd. for $\mathrm{C}_{15} \mathrm{H}_{16} \mathrm{O}_{4} \mathrm{~S}, 315.0667$; found, 315.0642 .

1,4-Dimethoxy-2-tosylbenzene (3q): White solid; m.p.: $111-113{ }^{\circ} \mathrm{C} .{ }^{1} \mathrm{H}$ NMR $(500 \mathrm{MHz}$, $\left.\mathrm{CDCl}_{3}\right): \delta(\mathrm{ppm}) 7.85(\mathrm{~d}, J=8.5 \mathrm{~Hz}, 2 \mathrm{H}), 7.68(\mathrm{~d}, J=3.0 \mathrm{~Hz}, 1 \mathrm{H}), 7.27(\mathrm{~d}, J=8.0 \mathrm{~Hz}, 2 \mathrm{H}), 7.06$ $(\mathrm{dd}, J=9.0 \mathrm{~Hz}, J=3.0 \mathrm{~Hz}, 1 \mathrm{H}), 6.84(\mathrm{~d}, J=9.0 \mathrm{~Hz}, 1 \mathrm{H}), 3.84(\mathrm{~s}, 3 \mathrm{H}), 3.71(\mathrm{~s}, 3 \mathrm{H}), 2.41(\mathrm{~s}, 3 \mathrm{H})$. ${ }^{13} \mathrm{C}$ NMR $\left(125 \mathrm{MHz}, \mathrm{CDCl}_{3}\right): \delta$ (ppm) 153.5, 151.4, 144.0, 138.7, 130.1, 129.3, 128.6, 121.7, 114.5, 113.9, 56.7, 56.3, 21.7. HRMS-ESI: $m / z[\mathrm{M}+\mathrm{Na}]^{+}$calcd. for $\mathrm{C}_{15} \mathrm{H}_{16} \mathrm{O}_{4} \mathrm{~S}, 315.0667$; found, 315.0700 .

4-((4-Chlorophenyl)sulfonyl)phenol (3r): White solid, m.p.: $146-147{ }^{\circ} \mathrm{C},{ }^{1} \mathrm{H}$ NMR $\left(500 \mathrm{MHz}, \mathrm{CDCl}_{3}\right): \delta(\mathrm{ppm}) 7.83(\mathrm{~d}, J=8.5 \mathrm{~Hz}, 2 \mathrm{H}), 7.80\left(\mathrm{~d}, J=9.0 \mathrm{~Hz}, 2 \mathrm{H}^{\prime}\right), 7.45(\mathrm{~d}$, $J=8.5 \mathrm{~Hz}, 2 \mathrm{H}), 6.91(\mathrm{~d}, J=9.0 \mathrm{~Hz}, 2 \mathrm{H}) .{ }^{13} \mathrm{C} \mathrm{NMR}\left(125 \mathrm{MHz}, \mathrm{CDCl}_{3}\right): \delta$ (ppm) 160.5, 140.9, $139.8,132.8,130.3,129.7,128.9,116.4$. HRMS-ESI: $m / z[\mathrm{M}+\mathrm{Na}]^{+}$calcd. for $\mathrm{C}_{12} \mathrm{H}_{9} \mathrm{O}_{3} \mathrm{SCl}$, 290.9859 ; found, 290.9894. 
2-((4-Chlorophenyl)sulfonyl)phenol (3r'): White solid, m.p.: $158-159{ }^{\circ} \mathrm{C},{ }^{1} \mathrm{H}$ NMR $\left(500 \mathrm{MHz} \mathrm{CDCl}_{3}\right): \delta(\mathrm{ppm}) 9.11(\mathrm{~s}, 1 \mathrm{H}), 7.88-7.86(\mathrm{~m}, 2 \mathrm{H}), 7.63(\mathrm{dd}, J=8.0 \mathrm{~Hz}, J=1.5 \mathrm{~Hz}$, $\left.2 \mathrm{H}^{\prime}\right), 7.51-7.45(\mathrm{~m}, 3 \mathrm{H}), 7.01-6.96(\mathrm{~m}, 2 \mathrm{H}) .{ }^{13} \mathrm{C} \mathrm{NMR}\left(125 \mathrm{MHz}, \mathrm{CDCl}_{3}\right): \delta$ (ppm) 155.9, $140.5,140.2,136.4,129.8,129.1,128.3,123.2,121.0,119.3$. HRMS-ESI: $m / z[\mathrm{M}+\mathrm{Na}]^{+}$calcd. for $\mathrm{C}_{12} \mathrm{H}_{9} \mathrm{O}_{3} \mathrm{SCl}, 290.9859$; found, 290.9895.

2-(Phenylsulfonyl)naphthalene (3s'): White solid, m.p.: $123-125^{\circ} \mathrm{C},{ }^{1} \mathrm{H} \mathrm{NMR}(500 \mathrm{MHz}$, $\left.\mathrm{CDCl}_{3}\right): \delta(\mathrm{ppm}) 8.58(\mathrm{~s}, 1 \mathrm{H}), 7.99(\mathrm{t}, J=7.5 \mathrm{~Hz}, 3 \mathrm{H}),, 7.93(\mathrm{~d}, J=9.0 \mathrm{~Hz}, 1 \mathrm{H}), 7.88-7.84(\mathrm{~m}$, 2H), 7.64-7.62 (m, 2H), 7.56-7.50 (m, 3H). $\left.{ }^{13} \mathrm{C} \mathrm{NMR} \mathrm{(125} \mathrm{MHz,} \mathrm{CDCl}_{3}\right): \delta(\mathrm{ppm}) 138.3,134.9$, 133.1, 132.2, 129.5, 129.3, 129.2, 129.1, 129.0, 128.7, 127.8, 127.6, 127.5, 122.6. HRMS-ESI: $m / z$ $[\mathrm{M}+\mathrm{Na}]^{+}$calcd. for $\mathrm{C}_{16} \mathrm{H}_{12} \mathrm{O}_{2} \mathrm{~S}, 291.0456$; found, 291.0445 .

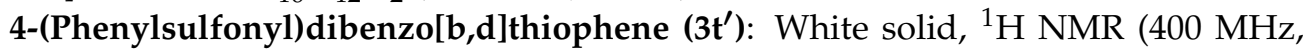
$\left.\mathrm{CDCl}_{3}\right): \delta(\mathrm{ppm}) 8.34(\mathrm{~d}, J=7.6 \mathrm{~Hz}, 1 \mathrm{H}), 8.19\left(\mathrm{~d}, J=7.6 \mathrm{~Hz}, 1 \mathrm{H}^{\prime}\right), 8.15(\mathrm{~d}, J=7.6 \mathrm{~Hz}, 1 \mathrm{H})$, $8.10(\mathrm{~d}, J=8.0 \mathrm{~Hz}, 2 \mathrm{H}), 7.91(\mathrm{~d}, J=7.6 \mathrm{~Hz}, 1 \mathrm{H}), 7.62(\mathrm{t}, J=7.6 \mathrm{~Hz}, 1 \mathrm{H}), 7.53-7.48(\mathrm{~m}, 5 \mathrm{H})$. ${ }^{13} \mathrm{C}$ NMR $\left(100 \mathrm{MHz}, \mathrm{CDCl}_{3}\right): \delta$ (ppm) 141.4, 140.8, 138.5, 138.3, 135.7, 134.4, 134.0, 131.3, $129.6,128.3,128.1,126.6,125.4,125.3,123.1,122.2$. MS $\left(\mathrm{C}_{18} \mathrm{H}_{12} \mathrm{O}_{2} \mathrm{~S}_{2}\right): m / z=324[\mathrm{M}]^{+}(78 \%)$, 199 (65\%), 183 (39\%), 171 (63\%), 139 (100\%), 77 (40\%), 51 (32\%).

4-Methoxy-2-methyl-1-tosylbenzene (3v): White solid; m.p.: 117-119 ${ }^{\circ} \mathrm{C} .{ }^{1} \mathrm{H} \mathrm{NMR}$ $\left(500 \mathrm{MHz}, \mathrm{CDCl}_{3}\right): \delta(\mathrm{ppm}) 8.15(\mathrm{~d}, J=9.0 \mathrm{~Hz}, 1 \mathrm{H}), 7.71(\mathrm{~d}, J=8.0 \mathrm{~Hz}, 2 \mathrm{H}), 7.27(\mathrm{~d}, J=7.5 \mathrm{~Hz}$, $2 \mathrm{H}), 6.85(\mathrm{dd}, J=8.5 \mathrm{~Hz}, J=2.5 \mathrm{~Hz}, 1 \mathrm{H}), 6.71(\mathrm{~d}, J=2.5 \mathrm{~Hz}, 1 \mathrm{H}), 3.83(\mathrm{~s}, 3 \mathrm{H}), 2.39(\mathrm{~s}, 6 \mathrm{H})$. ${ }^{13} \mathrm{C}$ NMR $\left(125 \mathrm{MHz}, \mathrm{CDCl}_{3}\right): \delta$ (ppm) 163.5, 143.7, 140.3, 139.3, 132.0, 131.2, 129.7, 127.6, 118.2, 111.1, 55.6, 21.7, 20.6. HRMS-ESI: $m / z[\mathrm{M}+\mathrm{Na}]^{+}$calcd. for $\mathrm{C}_{15} \mathrm{H}_{16} \mathrm{O}_{3} \mathrm{~S}, 299.0718$; found, 299.0715 .

2-Methoxy-4-methyl-1-tosylbenzene (3v') white solid; m.p.: $128-130{ }^{\circ} \mathrm{C} .{ }^{1} \mathrm{H}$ NMR $\left(500 \mathrm{MHz}, \mathrm{CDCl}_{3}\right): \delta(\mathrm{ppm}) 8.00(\mathrm{~d}, J=8.0 \mathrm{~Hz}, 1 \mathrm{H}), 7.83(\mathrm{~d}, J=8.5 \mathrm{~Hz}, 2 \mathrm{H}), 7.25(\mathrm{~d}, J=7.5 \mathrm{~Hz}$, $2 \mathrm{H}), 6.89(\mathrm{~d}, J=8.0 \mathrm{~Hz}, 1 \mathrm{H}), 6.68(\mathrm{~s}, 1 \mathrm{H}), 3.74(\mathrm{~s}, 3 \mathrm{H}), 2.40(\mathrm{~s}, 1 \mathrm{H}), 2.37(\mathrm{~s}, 3 \mathrm{H}) .{ }^{13} \mathrm{C} \mathrm{NMR}$ $\left(125 \mathrm{MHz}_{1} \mathrm{CDCl}_{3}\right): \delta$ (ppm) 156.9, 146.5, 143.4, 138.9, 129.7, 129.0, 128.2, 126.5, 121.1, 113.0, 55.7, 21.8, 21.4. HRMS-ESI: $m / z$ [M + Na] ${ }^{+}$calcd. for $\mathrm{C}_{15} \mathrm{H}_{16} \mathrm{O}_{3} \mathrm{~S}, 299.0718$; found, 299.0746 .

1-Methoxy-3-methyl-1-tosylbenzene (3v"): White solid; m.p.: 107-109 ${ }^{\circ} \mathrm{C} .{ }^{1} \mathrm{H} \mathrm{NMR}$ $\left(500 \mathrm{MHz}, \mathrm{CDCl}_{3}\right): \delta(\mathrm{ppm}) 7.79(\mathrm{~d}, J=8.5 \mathrm{~Hz}, 2 \mathrm{H}, 7.33(\mathrm{t}, J=8.0 \mathrm{~Hz}, 1 \mathrm{H}), 7.25(\mathrm{~d}, J=8.0 \mathrm{~Hz}$, $2 \mathrm{H}), 6.87(\mathrm{~d}, J=7.5 \mathrm{~Hz}, 1 \mathrm{H}), 6.73(\mathrm{~d}, J=8.5 \mathrm{~Hz}, 1 \mathrm{H}), 3.61(\mathrm{~s}, 3 \mathrm{H}), 2.84(\mathrm{~s}, 3 \mathrm{H}), 2.40(\mathrm{~s}, 3 \mathrm{H})$. ${ }^{13} \mathrm{C}$ NMR (125 MHz, $\left.\mathrm{CDCl}_{3}\right): \delta$ (ppm) 158.3, 143.2, 141.2, 141.1, 133.8, 128.9, 128.3, 127.4, 125.5, 110.9, 56.0, 22.4, 21.6. HRMS-ESI: $m / z[\mathrm{M}+\mathrm{Na}]^{+}$calcd. for $\mathrm{C}_{15} \mathrm{H}_{16} \mathrm{O}_{3} \mathrm{~S}, 299.0718$; found, 299.0702 .

1,2-Dimethoxy-4-tosylbenzene (3w) white solid; m.p.: $130-132{ }^{\circ} \mathrm{C} .{ }^{1} \mathrm{H}$ NMR $(500 \mathrm{MHz}$, $\left.\mathrm{CDCl}_{3}\right): \delta(\mathrm{ppm}) 7.80(\mathrm{~d}, J=8.5 \mathrm{~Hz}, 2 \mathrm{H}), 7.55(\mathrm{dd}, J=8.5 \mathrm{~Hz}, J=2.0 \mathrm{~Hz}, 1 \mathrm{H}), 7.37(\mathrm{~d}$, $J=2.5 \mathrm{~Hz}, 1 \mathrm{H}), 7.28(\mathrm{~d}, J=8.0 \mathrm{~Hz}, 2 \mathrm{H}), 6.91(\mathrm{~d}, J=8.5 \mathrm{~Hz}, 1 \mathrm{H}), 3.91(\mathrm{~s}, 3 \mathrm{H}), 3.90(\mathrm{~s}, 3 \mathrm{H})$, 2.39 (s, 3H). ${ }^{13} \mathrm{C}$ NMR $\left(125 \mathrm{MHz} \mathrm{CDCl}_{3}\right): \delta$ (ppm) 152.9, 149.3, 143.8, 139.4, 133.6, 129.8, 127.3, 121.7, 110.9, 109.9, 56.3, 56.2, 21.5. HRMS-ESI: $m / z[\mathrm{M}+\mathrm{H}]^{+}$calcd. for $\mathrm{C}_{15} \mathrm{H}_{16} \mathrm{O}_{4} \mathrm{~S}$, 293.0847; found, 293.0850.

1,2-Dimethoxy-3-tosylbenzene (3w'): White solid; m.p.: $128-130{ }^{\circ} \mathrm{C} .{ }^{1} \mathrm{H} \mathrm{NMR}(500 \mathrm{MHz}$, $\left.\mathrm{CDCl}_{3}\right): \delta(\mathrm{ppm}) 7.85(\mathrm{~d}, J=8.0 \mathrm{~Hz}, 2 \mathrm{H}), 7.70(\mathrm{~d}, J=8.0 \mathrm{~Hz}, 1 \mathrm{H}), 7.26(\mathrm{~d}, J=7.5 \mathrm{~Hz}, 2 \mathrm{H}), 7.18$ $(\mathrm{t}, J=8.0 \mathrm{~Hz}, 1 \mathrm{H}), 7.11(\mathrm{~d}, J=8.5 \mathrm{~Hz}, 1 \mathrm{H}), 3.86(\mathrm{~s}, 3 \mathrm{H}), 3.83(\mathrm{~s}, 3 \mathrm{H}), 2.39(\mathrm{~s}, 3 \mathrm{H}) .{ }^{13} \mathrm{C} \mathrm{NMR}$ $\left(125 \mathrm{MHz} \mathrm{CDCl}_{3}\right): \delta$ (ppm) 153.8, 147.4, 144.0, 139.1, 135.8, 129.4, 128.3, 123.9, 120.6, 117.8, 61.5, 56.3, 21.7. HRMS-ESI: $m / z[\mathrm{M}+\mathrm{H}]^{+}$calcd. for $\mathrm{C}_{15} \mathrm{H}_{16} \mathrm{O}_{4} \mathrm{~S}, 293.0847$; found, 293.0846 .

\section{Conclusions}

Using contemporary green chemistry, a chloroaluminate ionic liquid immobilized on magnetic nanoparticles was developed and applied in the solvent-free sulfonylation of substituted aromatic compounds with sulfonyl chlorides, as well as $p$-toluenesulfonic anhydride, to afford sulfones in moderate to good yields. The Friedel-Crafts sulfonylation had preferred arenes and sulfonyl chlorides with electron-donating substituents. The more electron-donating substituents on the aromatic rings, the more the yields of sulfones, and the shorter the reaction times. In addition, another interesting result was that the size of the $\mathrm{Fe}_{3} \mathrm{O}_{4}$ particles, which originally were around $20 \mathrm{~nm}$ in diameter, became smaller, in 
the range of 6-14 $\mathrm{nm}$ in diameter, owing to the immobilization of the chloroaluminate ionic liquid on the particles. Furthermore, $\mathrm{Fe}_{3} \mathrm{O}_{4} @ \mathrm{O}_{2} \mathrm{Si}[\mathrm{PrMIM}] \mathrm{Cl} \cdot \mathrm{AlCl}_{3}$ is an ecofriendly, efficient, and highly recyclable catalyst, especially evidenced by the yields of sulfones without a significant drop after four catalytic cycles of recovery and reuse.

Supplementary Materials: The following are available online. ${ }^{1} \mathrm{H}-\mathrm{NMR},{ }^{13} \mathrm{C}-\mathrm{NMR}$, and HRMS of unknown products. Figure S1. BET surface area of $\mathrm{Fe}_{3} \mathrm{O}_{4} @ \mathrm{O}_{2} \mathrm{Si}[\mathrm{PrMIM}] \mathrm{Cl} \cdot \mathrm{AlCl}$, Figure S2. 1H-NMR of 1-((4-chlorophenyl)sulfonyl)-2-methylbenzene (3c' $)$; Figure S3. 13C-NMR of 1-((4-chlorophenyl)sulfonyl)-2-methylbenzene $\left(3 c^{\prime}\right)$.

Author Contributions: T.X.T.L. conceived and designed the experiments and wrote the paper; N.-L.T.N. mainly performed the experiments and wrote the original draft preparation; Q.-A.N., K.-N.T.T., and P.-B.P. performed the experiments and analyzed the data; T.K.L. analyzed the data and reviewed and edited the paper. All authors have read and agreed to the published version of the manuscript.

Funding: This research was funded by Vietnam National University, Ho Chi Minh City (VNU-HCM) under grant number C2020-18-13.

Institutional Review Board Statement: Not applicable.

Informed Consent Statement: Not applicable.

Data Availability Statement: Not applicable.

Acknowledgments: We acknowledge Phu-Thanh Pham, Kim-Yen Tran, Thu-Ha Thi Phan, DuyKhiem Vo Tran (Ho Chi Minh University of Science), and Fritz Duus (Roskilde University) for technical assistance and chemical support.

Conflicts of Interest: The authors declare no conflict of interest.

\section{References}

1. Padwa, A.; Bullock, W.H.; Dyszlewski, A.D. Studies dealing with the alkylation-[1,3]-rearrangement reaction of some phenylthiosubstituted allylic sulfones. J. Org. Chem. 1990, 55, 955-964. [CrossRef]

2. Block, E. The organosulfur chemistry of the Genus Allium-Implications for the organic chemistry of sulfur. Angew. Chem. Int. Ed. 1992, 31, 1135-1178. [CrossRef]

3. Shaaban, O.; Rizk, O.; Bayad, A.; El-Ashmawy, I. Synthesis of some 4,5-Dihydrothieno[3,2-e][1,2,4]triazolo[4,3-a] Pyrimi-dine-2carboxamides as anti-inflammatory and analgesic agents. Open J. Med. Chem. 2013, 7, 49-65. [CrossRef]

4. Hwang, S.H.; Wagner, K.M.; Morisseau, C.; Liu, J.Y.; Dong, H.; Wecksler, A.T.; Hammock, B.D. Synthesis and structure-activity relationship studies of urea-containing pyrazoles as dual inhibitors of cyclooxygenase-2 and soluble epoxide hydrolase. J. Med. Chem. 2011, 54, 3037-3050. [CrossRef] [PubMed]

5. Meadows, D.C.; Sanchez, T.; Neamati, N.; North, T.W.; Gervay-Hague, J. Ring substituent effects on biological activity of vinyl sulfones as inhibitors of HIV-1. Bioorg. Med. Chem. 2007, 15, 1127-1137. [CrossRef]

6. Capela, R.; Oliveira, R.; Gonçalves, L.M.; Domingos, A.; Gut, J.; Rosenthal, P.J.; Lopes, F.; Moreira, R. Artemisinin-dipeptidyl vinyl sulfone hybrid molecules: Design, synthesis and preliminary SAR for antiplasmodial activity and falcipain-2 inhibition. Bioorg. Med. Chem. Lett. 2009, 19, 3229-3232. [CrossRef] [PubMed]

7. Rosenthal, A.S.; Chen, X.; Liu, J.O.; West, D.C.; Hergenrother, P.J.; Shapiro, T.A.; Posner, G.H. Malaria-infected mice are cured by a single oral dose of new dimeric trioxane sulfones which are also selectively and powerfully cytotoxic to cancer cells. J. Med. Chem. 2009, 52, 1198-1203. [CrossRef]

8. Al-Said, M.S.; Ghorab, M.M.; Nissan, Y.M. Dapson in heterocyclic chemistry, part VIII: Synthesis, molecular docking and anticancer activity of some novel sulfonylbiscompounds carrying biologically active 1,3-dihydropyridine, chromene and chromenopyridine moieties. Chem. Cent. J. 2012, 6, 64. [CrossRef] [PubMed]

9. Soni, S.; Seth, M.; Sah, P. Synthesis and in-vitro antimicrobial evaluation of some novel phthalyl substituted aryl sulphones and sulphonamides. Res. J. Pharm. Biol. Chem. Sci. 2012, 3, 898-907.

10. Li, P.; Yin, J.; Xu, W.; Wu, J.; He, M.; Hu, D.; Yang, S.; Song, B. Synthesis, antibacterial activities, and 3D-QSAR of sulfone derivatives containing 1, 3, 4-oxadiazole moiety. Chem. Biol. Drug Chem. 2013, 82, 546-556. [CrossRef] [PubMed]

11. Chen, Y.T.; Lira, R.; Hansell, E.; McKerrow, J.H.; Roush, W.R. Synthesis of macrocyclic trypanosomal cysteine protease inhibitors. Bioorg. Med. Chem. Lett. 2008, 18, 5860-5863. [CrossRef] [PubMed]

12. Jereb, M. Highly atom-economic, catalyst- and solvent-free oxidation of sulfides into sulfones using $30 \%$ aqueous $\mathrm{H}_{2} \mathrm{O}_{2}$. Green Chem. 2012, 14, 3047-3052. [CrossRef] 
13. Kirihara, M.; Itou, A.; Noguchi, T.; Yamamoto, J. Tantalum carbide or niobium carbide catalyzed oxidation of sulfides with hydrogen peroxide: Highly efficient and chemoselective syntheses of sulfoxides and sulfones. Synlett 2010, $2010,1557-1561$. [CrossRef]

14. Pritzius, A.B.; Breit, B. Asymmetric rhodium-catalyzed addition of thiols to allenes: Synthesis of branched allylic thioethers and sulfones. Angew. Chem. Int. Ed. 2015, 54, 3121-3125. [CrossRef] [PubMed]

15. Maloney, K.M.; Kuethe, J.T.; Linn, K. A practical, one-pot synthesis of sulfonylated pyridines. Org. Lett. 2011, 13, 102-105. [CrossRef] [PubMed]

16. Umierski, N.; Manolikakes, G. Metal-free synthesis of diaryl sulfones from arylsulfinic acid salts and diaryliodonium salts. Org. Lett. 2013, 15, 188-191. [CrossRef] [PubMed]

17. Pandya, V.G.; Mhaske, S.B. Transition-metal-free C-S bond formation: A facile access to aryl sulfones from sodium sulfinates via arynes. Org. Lett. 2014, 16, 3836-3839. [CrossRef]

18. Taniguchi, N. Aerobic copper-catalyzed synthesis of $(E)$-alkenyl sulfones and $(E)$ - $\beta$-halo-alkenyl sulfones via addition of sodium sulfinates to alkynes. Tetrahedron 2014, 70, 1984-1990. [CrossRef]

19. Yang, W.; Yang, S.; Li, P.; Wang, L. Visible-light initiated oxidative cyclization of phenyl propiolates with sulfinic acids to coumarin derivatives under metal-free conditions. Chem. Commun. 2015, 51,7520-7523. [CrossRef]

20. Chen, J.; Mao, J.; Zheng, Y.; Liu, D.; Rong, G.; Yan, H.; Zhang, C.; Shi, D. Iodine-promoted decarboxylative C-S cross-coupling of cinnamic acids with sodium benzene sulfinates. Tetrahedron 2015, 71, 5059-5063. [CrossRef]

21. Truce, W.E.; Milionis, J.P. Friedel-Crafts cyclization of ı-phenylalkanesulfonyl chlorides. J. Am. Chem. Soc. 1952, 74, 974-977. [CrossRef]

22. Truce, W.E.; Vriesen, C.W. Friedel - Crafts reactions of methanesulfonyl chloride with benzene and certain substituted benzenes J. Am. Chem. Soc. 1953, 75, 5032-5036. [CrossRef]

23. Jensen, F.R.; Brown, H.C. Kinetics of the Friedel-Crafts sulfonylation of aromatics with aluminum chloride as catalyst and nitrobenzene as solvent. J. Am. Chem. Soc. 1958, 80, 4038-4041. [CrossRef]

24. Olah, G.A.; Kobayashi, S.; Nishimura, J. Aromatic substitution. XXXI. Friedel-Crafts sulfonylation of benzene and toluene with alkyl- and arylsulfonyl halides and anhydrides. J. Am. Chem. Soc. 1973, 95, 564-569. [CrossRef]

25. Marquié, J.; Laporterie, A.; Dubac, J.; Roques, N.; Desmurs, J.-R. Acylation and related reactions under microwaves. 4. Sulfonylation reactions of aromatics. J. Org. Chem. 2001, 66, 421-425. [CrossRef]

26. Fleck, T.J.; Chen, J.J.; Lu, C.V.; Hanson, K.J. Isomerization-free sulfonylation and its application in the synthesis of PHA-565272A Org. Process Res. Dev. 2006, 10, 334-338. [CrossRef]

27. Bandgar, B.P.; Kasture, S.P. Zinc-Mediated fast sulfonylation of aromatics. Synth. Commun. 2001, 31, 1065-1068. [CrossRef]

28. Jang, D.O.; Moon, K.S.; Cho, D.H.; Kim, J.-G. Highly selective catalytic Friedel-Crafts acylation and sulfonylation of activated aromatic compounds using indium metal. Tetrahedron Lett. 2006, 47, 6063-6066. [CrossRef]

29. De Noronha, R.G.; Fernandes, A.C.; Romão, C.C. $\mathrm{MoO}_{2} \mathrm{Cl}_{2}$ as a novel catalyst for Friedel-Crafts acylation and sulfonylation. Tetrahedron Lett. 2009, 50, 1407-1410. [CrossRef]

30. Singh, R.P.; Kamble, R.M.; Chandra, K.L.; Saravanan, P.; Singh, V.K. An efficient method for aromatic Friedel-Crafts alkylation, acylation, benzoylation, and sulfonylation reactions. Tetrahedron 2001, 57, 241-247. [CrossRef]

31. Nguyen, V.T.A.; Duus, F.; Le, T.N. Upward trend in catalytic efficiency of rare-earth triflate catalysts in Friedel-Crafts aromatic sulfonylation reactions. Asian J. Org. Chem. 2014, 3, 963-968. [CrossRef]

32. Jin, T.; Zhao, Y.; Ma, Y.; Li, T. A practical and efficient method for the preparation of aromatic sulfones by the reaction of aryl sulfonyl chlorides with arenes catalyzed by $\mathrm{Fe}(\mathrm{OH})_{3}$. Indian J. Chem. 2005, 44B, 2183-2185. [CrossRef]

33. Olah, G.A.; Mathew, T.; Surya Prakash, G.K. Nafion-H catalysed sulfonylation of aromatics with arene/alkenesulfonic acids for the preparation of sulfones. Chem. Commun. 2001, 17, 1696-1697. [CrossRef] [PubMed]

34. Choudary, B.M.; Chowdari, N.S.; Kantam, M.L.; Kannan, R. Fe(III) exchanged montmorillonite: A mild and ecofriendly catalyst for sulfonylation of aromatics. Tetrahedron Lett. 1999, 40, 2859-2862. [CrossRef]

35. Borujeni, K.P.; Tamami, B. Polystyrene and silica gel supported $\mathrm{AlCl}_{3}$ as highly chemoselective heterogeneous Lewis acid catalysts for Friedel-Crafts sulfonylation of aromatic compounds. Catal. Commun. 2007, 8, 1191-1196. [CrossRef]

36. Boroujeni, K.P. Sulfonylation of aromatic compounds with sulfonic acids using silica gel-supported $\mathrm{AlCl}_{3}$ as a heterogeneous Lewis acid catalyst. J. Sulphur. Chem. 2010, 31, 197-203. [CrossRef]

37. Nara, S.J.; Harjani, J.R.; Salunkhe, M.M. Friedel-Crafts sulfonylation in 1-Butyl-3-methylimidazolium chloroaluminate ionic liquids. J. Org. Chem. 2001, 66, 8616-8620. [CrossRef]

38. Bahrami, K.; Khodei, M.M.; Shahbazi, F. Highly selective catalytic Friedel-Crafts sulfonylation of aromatic compounds using a $\mathrm{FeCl}_{3}$-based ionic liquid. Tetrahedron Lett. 2008, 49, 3931-3934. [CrossRef]

39. Hajipour, A.R.; Zarei, A.; Khazdooz, L.; Pourmousavi, S.A.; Mirjalili, B.B.F.; Ruoho, A.E. Direct sulfonylation of aromatic rings with aryl or alkyl sulfonic acid using supported $\mathrm{P}_{2} \mathrm{O}_{5} / \mathrm{Al}_{2} \mathrm{O}_{3}$. Phosphorus Sulfur Silicon Relat. Elem. 2006, 180, 2029-2034. [CrossRef]

40. Mirjalili, F.; Zolfigol, M.A.; Bamoniri, A.; Khazdooz, L. An efficient method for the sulfonylation of aromatic rings with arene/alkane sulfonic acid by using $\mathrm{P}_{2} \mathrm{O}_{5} / \mathrm{SiO}_{2}$ under heterogeneous conditions. Bull. Korean Chem. Soc. 2003, 24, 1009-1010. [CrossRef]

41. Zhao, D.; Wu, M.; Kou, Y.; Min, E. Ionic liquids: Applications in catalysis. Catal. Today 2002, 74, 157-189. [CrossRef] 
42. Boroujeni, K.P.; Jafarinasab, M. Polystyrene-supported chloroaluminate ionic liquid as a new heterogeneous Lewis acid catalyst for Knoevenagel condensation. Chin. Chem. Lett. 2012, 23, 1067-1070. [CrossRef]

43. Mouradzadegun, A.; Elahi, S.; Abadast, F. Synthesis of a 3D-network polymer supported Bronsted acid ionic liquid based on calix[4]resorcinarene via two post-functionalization steps: A highly efficient and recyclable acid catalyst for the preparation of symmetrical bisamides. RSC Adv. 2014, 4, 31239-31248. [CrossRef]

44. Wei-Li, D.; Bi, J.; Sheng-Lian, L.; Xu-Biao, L.; Xin-Man, T.; Chak-Tong, A. Polymers anchored with carboxyl-functionalized di-cation ionic liquids as efficient catalysts for the fixation of $\mathrm{CO}_{2}$ into cyclic carbonates. Catal. Sci. Technol. 2014, 4, 556-562 [CrossRef]

45. Khoshnevis, M.; Davoodnia, A.; Zare-Bidaki, A.; Tavakoli-Hoseini, N. Alumina supported acidic ionic liquid: Preparation, characterization, and its application as catalyst in the synthesis of 1,8-dioxo-octahydroxanthenes. Synth. React. Inorg. Met. Org. Nano-Met. Chem. 2013, 43, 1154-1161. [CrossRef]

46. Tamboli, A.H.; Chaugule, A.A.; Sheikh, F.A.; Chung, W.-J.; Kim, H. Synthesis, characterization, and application of silica supported ionic liquid as catalyst for reductive amination of cyclohexanone with formic acid and triethyl amine as hydrogen source. Chin. J. Catal. 2015, 36, 1365-1371. [CrossRef]

47. Hu, Y.L.; Fang, D. Preparation of silica supported ionic liquids for highly selective hydroxylation of aromatics with hydrogen peroxide under solvent-free conditions. J. Mex. Chem. Soc. 2016, 60, 207-217. [CrossRef]

48. Qian, C.; Yao, C.; Yang, L.; Yang, B.; Liu, S.; Liu, Z. Preparation and application of silica films supported imidazolium-based ionic liquid as efficient and recyclable catalysts for benzoin condensations. Catal. Lett. 2020, 150, 1389-1396. [CrossRef]

49. Shojaei, R.; Zahedifar, M.; Mohammadi, P.; Saidi, K.; Sheibani, H. Novel magnetic nanoparticle supported ionic liquid as an efficient catalyst for the synthesis of spiro [pyrazole-pyrazolo[3,4-b]pyridine]-dione derivatives under solvent free conditions. $J$. Mol. Struct. 2019, 1178, 401-407. [CrossRef]

50. Safari, J.; Zarnegar, Z. Brønsted acidic ionic liquid based magnetic nanoparticles: A new promoter for the Biginelli synthesis of 3,4-dihydropyrimidin-2(1H)-ones/thiones. New J. Chem. 2014, 38, 358-365. [CrossRef]

51. Li, P.-H.; Li, B.-L.; Hu, H.-C.; Zhao, X.-N.; Zhang, Z.-H. Ionic liquid supported on magnetic nanoparticles as highly efficient and recyclable catalyst for the synthesis of $\beta$-keto enol ethers. Catal. Commun. 2014, 46, 118-122. [CrossRef]

52. Naeimi, H.; Aghaseyedkarimi, D. $\mathrm{Fe}_{3} \mathrm{O}_{4} @ \mathrm{SiO}_{2} \cdot \mathrm{HM} \cdot \mathrm{SO}_{3} \mathrm{H}$ as a recyclable heterogeneous nanocatalyst for the microwave-promoted synthesis of 2,4,5-trisubstituted imidazoles under solvent free conditions. New J. Chem. 2015, 39, 9415-9421. [CrossRef]

53. Ghorbani-Choghamarani, A.; Norouzi, M. Synthesis and characterization of ionic liquid immobilized on magnetic nanoparticles: A recyclable heterogeneous organocatalyst for the acetylation of alcohols. J. Magn. Magn. Mater. 2016, 401, 832-840. [CrossRef]

54. Ghorbani-Choghamarani, A.; Taherinia, Z.; Nikoorazm, M. Ionic liquid supported on magnetic nanoparticles as a novel reusable nanocatalyst for the efficient synthesis of tetracyclic quinazoline compounds. Res. Chem. Intermed. 2018, 44, 6591-6604. [CrossRef]

55. Naikwade, A.; Jagadale, M.; Kale, D.; Rashinkar, G. Magnetic nanoparticle supported ionic liquid phase catalyst for oxidation of alcohols. Aust. J. Chem. 2020, 73, 1088-1097. [CrossRef]

56. Safari, J.; Zarnegar, Z. Immobilized ionic liquid on superparamagnetic nanoparticles as an effective catalyst for the synthesis of tetrasubstituted imidazoles under solvent-free conditions and microwave irradiation. Comptes Rendus Chim. 2013, 16, 920-928. [CrossRef]

57. Zhang, Q.; Su, H.; Luo, J.; Wei, Y. A magnetic nanoparticle supported dual acidic ionic liquid: A "quasi-homogeneous" catalyst for the one-pot synthesis of benzoxanthenes. Green Chem. 2012, 14, 201-208. [CrossRef]

58. Azgomi, N.; Mokhtary, M. Nano-Fe $\mathrm{O}_{4} @ \mathrm{SiO}_{2}$ supported ionic liquid as an efficient catalyst for the synthesis of 1,3-thiazolidin-4ones under solvent-free conditions. J. Mol. Catal. A Chem. 2015, 398, 58-64. [CrossRef]

59. Ngo, H.N.T.; Nguyen, N.L.T.; Luu, X.T.T. The Friedel-Crafts sulfonylation catalyzed by chloroaluminate ionic liquids. Sci. Tech Dev. J. Nat. Sci. 2021, 5, 1581-1592.

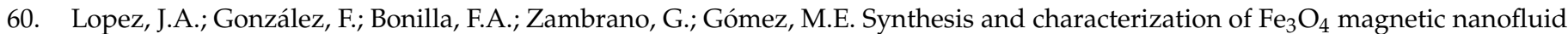
Rev. Latinoam. Metal. Mater. 2010, 30, 60-66.

61. Nazari, S.; Saadat, S.; Fard, P.K.; Gorjizadeh, M.; Nezhad, E.R.; Afshari, M. Imidazole functionalized magnetic Fe ${ }_{3} \mathrm{O}_{4}$ nanoparticles as a novel heterogeneous and efficient catalyst for synthesis of dihydropyrimidinones by Biginelli reaction. Monatsh. Chem. 2013, 144, 1877-1882. [CrossRef]

62. Choudary, B.M.; Chowdari, N.S.; Kantam, M.L. Friedel-Crafts sulfonylation of aromatics catalysed by solid acids: An eco-friendly route for sulfone synthesis. J. Chem. Soc. Perkin Trans. I 2000, 16, 2689-2693. [CrossRef]

63. Yang, M.; Shen, H.; Li, Y.; Shen, C.; Zhang, P. d-Glucosamine as a green ligand for copper catalyzed synthesis of aryl sulfones from aryl halides and sodium sulfinates. RSC Adv. 2014, 4, 26295-26300. [CrossRef]

64. Liang, X.; Li, Y.; Xia, Q.; Cheng, L.; Guo, J.; Zhang, P.; Zhang, W.; Wang, Q. Visible-light-driven electron donor-acceptor complex induced sulfonylation of diazonium salts with sulfinates. Green Chem. 2021, 23, 8865-8870. [CrossRef]

65. Bandgar, B.P.; Bettigeri, S.V.; Phopase, J. Unsymmetrical diaryl sulfones through palladium-catalyzed coupling of aryl boronic acids and arylsulfonyl chlorides. Org. Lett. 2004, 6, 2105-2108. [CrossRef] [PubMed]

66. Bian, M.; Ma, C.; Xu, F. Anion-functionalized ionic liquids enhance the CuI-catalyzed cross-coupling reaction of sulfinic acid salts with aryl halides and vinyl bromides. Synthesis 2007, 2007, 2951-2956. [CrossRef]

67. Cooke, M.; Clark, J.; Breeden, S. Lewis acid catalysed microwave-assisted synthesis of diaryl sulfones and comparison of associated carbon dioxide emissions. J. Mol. Catal. A Chem. 2009, 303, 132-136. [CrossRef] 
68. Deeming, A.S.; Russell, C.J.; Hennessy, A.J.; Willis, M.C. DABSO-based, three-component, one-pot sulfone synthesis. Org. Lett. 2014, 16, 150-153. [CrossRef]

69. Chandrasekaran, R.; Perumal, S.; Wilson, D.A. NMR study of substituent effects in 4-substituted and 4,4'-disubstituted diphenyl sulphoxides and sulphones. Magn. Reson. Chem. 1989, 27, 360-367. [CrossRef]

70. Srinivas, B.T.V.; Rawat, V.S.; Konda, K.; Sreedhar, B. Magnetically separable copper ferrite nanoparticles-catalyzed synthesis of diaryl, alkyl/aryl sulfones from arylsulfinic acid salts and organohalides/boronic acids. Adv. Synth. Catal. 2014, 356, 805-817. [CrossRef]

71. Sharghi, $\mathrm{H}$.; Shahsavari-Fard, $\mathrm{Z}$. $\mathrm{Al}_{2} \mathrm{O}_{3} / \mathrm{MeSO}_{3} \mathrm{H}$ (AMA) a useful system for direct sulfonylation of phenols with $p$-toluenesulfonic acid. J. Iran. Chem. Soc. 2005, 2, 47-53. [CrossRef] 